\title{
Explosive Detection and Identification by PGNAA
}

\author{
E. H. Seabury \\ A. J. Caffrey
}

November 2004

Idaho National Engineering and Environmental Laboratory Bechtel BWXT Idaho, LLC 


\title{
Explosive Detection and Identification by PGNAA
}

\author{
E. H. Seabury \\ A. J. Caffrey \\ November 2004 \\ Idaho National Engineering and Environmental Laboratory \\ Idaho Falls, Idaho 83415
}

Prepared for the U.S. Department of Energy

Under DOE Idaho Operations Office

Contract DE-AC07-99ID13727 


\begin{abstract}
Is it feasible to use field-portable prompt gamma-ray neutron activation analysis (PGNAA) to detect and identify explosives in improvised nuclear devices?

We have studied this question computationally, using the Monte Carlo NParticle (MCNP) code developed at Los Alamos National Laboratory. The Monte Carlo results, in turn were tested experimentally using explosive simulants and the PINS PGNAA system developed at Idaho National Engineering and Environmental Laboratory (INEEL). The results of the MCNP calculations and PINS measurements are presented in this report.
\end{abstract}

The calculations and measurements were in good agreement and indicate that most explosives are readily distinguishable from one another by PGNAA, and it appears the answer to the question posed above is a conclusive "yes." 


\section{CONTENTS}

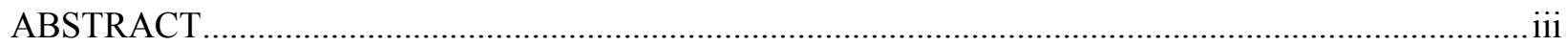

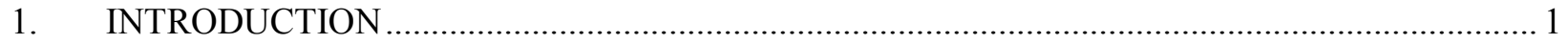

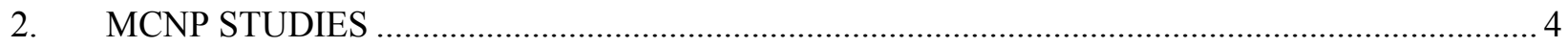

3. PINS MEASUREMENTS AND COMPARISON WITH MCNP …........................................ 11

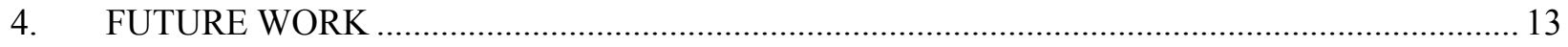

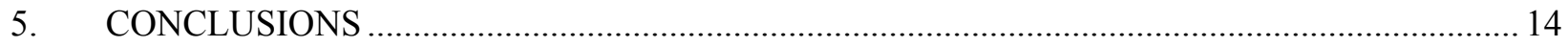

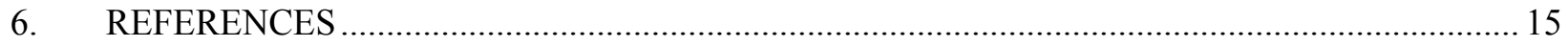

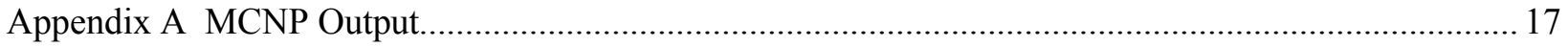

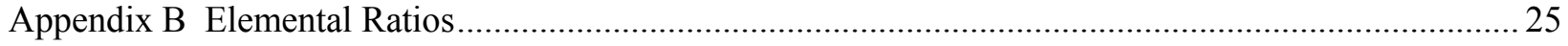

\section{FIGURES}

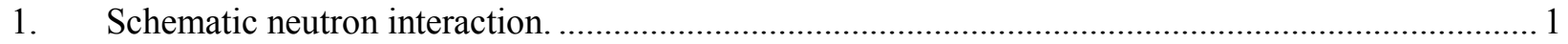

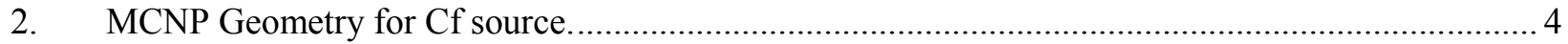

3. MCNP Geometry for neutron generator sources...................................................................... 5

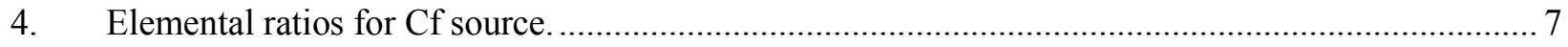

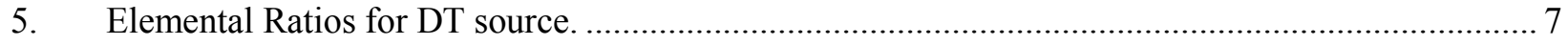

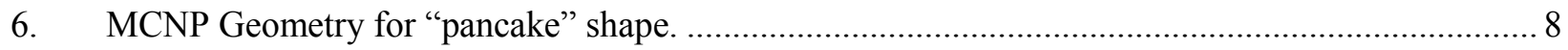

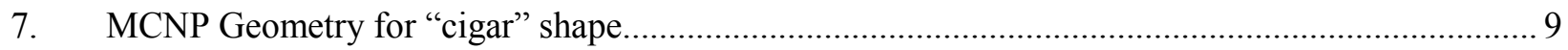

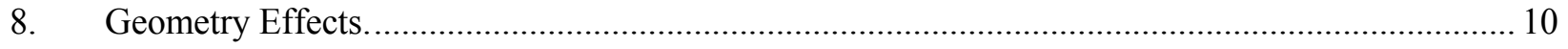

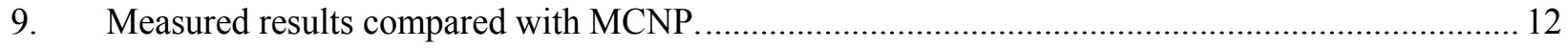

\section{TABLES}

1. Elemental Composition of CW Agents in weight percent.......................................................... 2

2. Elemental Composition of Explosives in weight percent......................................................... 2

3. Designations and Chemical Formulas of Explosives …............................................................. 3 


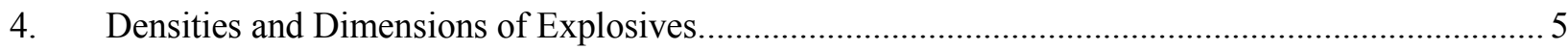

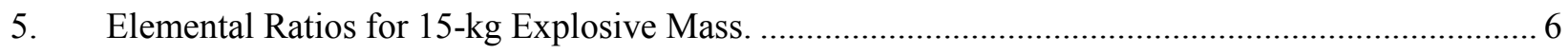

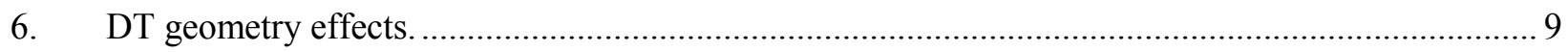

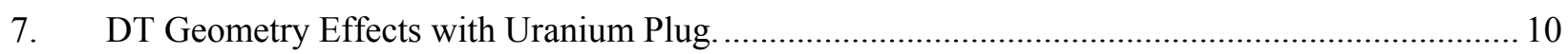

8. Elemental Composition of Explosives and Simulants in weight percent. .................................... 11

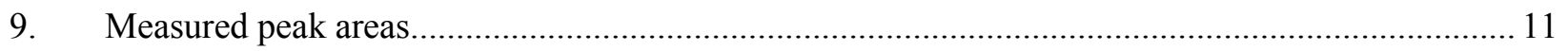

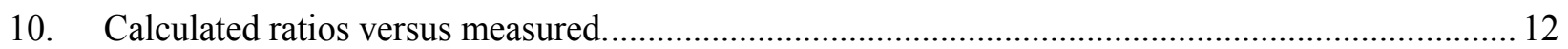




\section{Explosive Detection and Identification by PGNAA \\ 1. INTRODUCTION}

In FY-2003, DOE/NA-42 officials asked us if INEEL's Portable Isotopic Neutron Spectroscopy System $^{1}$ (PINS) could be adapted to detect and identify explosives, if any, within a suspect improvised nuclear device (IND). We report here our FY-2004 study of this problem. Most of our research was performed via a series of Monte Carlo experiments using the Los Alamos MCNP transport code ${ }^{2}$; we also carried out a small set of laboratory experiments to verify the Monte Carlo results.

PINS employs neutron radiation to probe the chemical elements within a container without the need to open or even touch the container. A radioisotopic neutron source or an electrical neutron generator shines neutrons on the item under test. The neutrons, in turn, penetrate the container or munition where they interact with the atomic nuclei of the filler material, producing gamma rays characteristic of the chemical elements inside the item. These energetic gamma rays can penetrate even the thick steel wall of an artillery projectile to escape and trigger a gamma-ray spectrometer. This technique is called Prompt Gamma-ray Neutron Activation Analysis (PGNAA). A schematic neutron reaction event is shown in Figure 1. The energies and intensities of these gamma rays, as measured by the spectrometer, identify the elemental composition of the fill material.

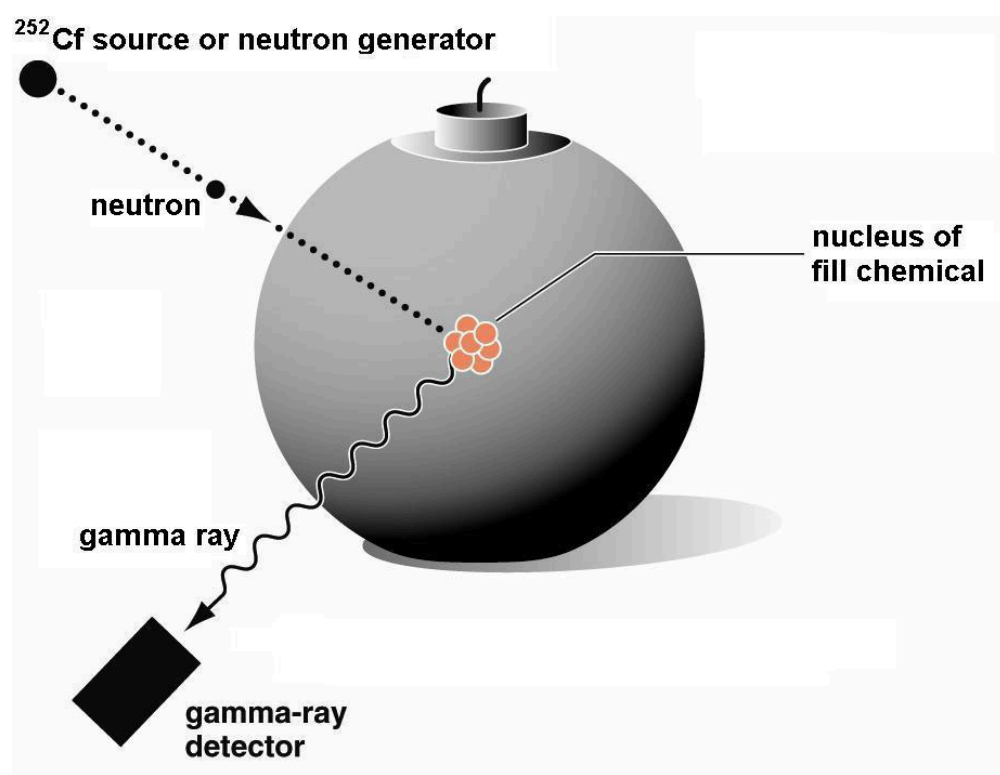

Figure 1. Schematic neutron interaction.

PGNAA has been demonstrated to be an effective tool for identifying contents of munitions and other containers suspected to contain explosives, smoke-generating chemicals, and chemical warfare agents such as mustard and nerve gas, and to this end, PINS is used routinely by the U.S. Army ${ }^{3}$, the Defense Threat Reduction Agency, and foreign military units.

Identifying explosives of a particular type is somewhat more difficult that identifying chemical warfare agents, however, because most explosives contain just four chemical elements, while the 
elemental compositions of chemical warfare agents vary broadly. For example, Table 1 shows the elemental compositions ${ }^{1}$ of some typical chemical warfare agents and Table 2 shows the compositions ${ }^{4,5}$ of the explosives examined in this project. The chemical formulas and designations of the explosives are shown in Table 3.

Table 1. Elemental Composition of CW Agents in weight percent.

\begin{tabular}{ccccccc}
\hline Element & $\begin{array}{c}\text { Sarin } \\
(\mathrm{GB})\end{array}$ & $\begin{array}{c}\text { Soman } \\
(\mathrm{GD})\end{array}$ & $\begin{array}{c}\text { Tabun } \\
(\mathrm{GA})\end{array}$ & $\mathrm{VX}$ & $\begin{array}{c}\text { Mustard } \\
(\mathrm{H})\end{array}$ & $\begin{array}{c}\text { Lewisite } \\
(\mathrm{L})\end{array}$ \\
\hline $\mathrm{H}$ & 7.1 & 8.8 & 6.8 & 9.7 & 5.0 & 1.0 \\
$\mathrm{C}$ & 34.3 & 46.2 & 37.0 & 49.4 & 30.2 & 11.4 \\
$\mathrm{O}$ & 22.9 & 17.6 & 19.8 & 12.0 & & \\
$\mathrm{~N}$ & & & & 17.3 & 5.2 & \\
$\mathrm{~F}$ & 13.6 & 10.4 & & & & \\
$\mathrm{P}$ & 22.1 & 17.0 & 19.1 & 11.6 & & \\
$\mathrm{~S}$ & & & & & \\
$\mathrm{Cl}$ & & & & & & \\
$\mathrm{As}$ & & & & & & \\
\end{tabular}

Table 2. Elemental Composition of Explosives in weight percent.

\begin{tabular}{cccccccccccc}
\hline & HMX & LX-17 & TNT & Comp. B & TATB & PBX-9501 & PBX-9502 & NM & ANFO & $\begin{array}{c}\text { Black } \\
\text { Powder }\end{array}$ & TATP \\
\hline H & 2.7 & 2.2 & 2.2 & 2.7 & 2.3 & 2.9 & 2.2 & 5.0 & 5.4 & -- & 8.2 \\
$\mathrm{C}$ & 16.2 & 27.5 & 37.0 & 24.3 & 27.9 & 17.7 & 27.6 & 19.7 & 2.6 & 9.3 & 48.6 \\
$\mathrm{O}$ & 43.2 & 34.4 & 42.3 & 42.6 & 37.2 & 43.0 & 35.3 & 52.4 & 58.1 & 35.2 & 43.2 \\
$\mathrm{~N}$ & 37.8 & 30.1 & 18.5 & 30.4 & 32.6 & 36.4 & 31.0 & 23.0 & 33.9 & 10.3 & -- \\
$\mathrm{Cl}$ & -- & 1.9 & -- & -- & -- & -- & 1.3 & -- & -- & -- & - \\
$\mathrm{F}$ & -- & 2.2 & -- & -- & -- & -- & 1.4 & -- & -- & -- & -- \\
$\mathrm{S}$ & -- & -- & -- & -- & -- & -- & -- & -- & -- & 16.5 & -- \\
$\mathrm{K}$ & -- & -- & -- & -- & -- & -- & -- & -- & -- & 28.7 & -- \\
\hline
\end{tabular}


Table 3. Designations and Chemical Formulas of Explosives

\begin{tabular}{|c|c|c|}
\hline Designation & Chemical Formula & Chemical Name \\
\hline HMX & $\mathrm{C}_{4} \mathrm{H}_{8} \mathrm{~N}_{8} \mathrm{O}_{8}$ & Octahydro-1,3,5,7-tetranitro-1,3,5,7-tetrazocine \\
\hline LX-17 & $92.5 \%$ TATB, $7.5 \%$ Kel-F $800\left(\mathrm{C}_{8} \mathrm{H}_{2} \mathrm{Cl}_{3} \mathrm{~F}_{11}\right)_{\mathrm{n}}$ & LX-17-0 \\
\hline TNT & $\mathrm{C}_{7} \mathrm{H}_{5} \mathrm{~N}_{3} \mathrm{O}_{6}$ & 2-methyl-1,3,5-trinitrobenzene \\
\hline Composition B & $63 \% \operatorname{RDX}\left(\mathrm{C}_{3} \mathrm{H}_{6} \mathrm{~N}_{6} \mathrm{O}_{6}\right), 36 \%$ TNT, $1 \%$ wax & -- \\
\hline TATB & $\mathrm{C}_{6} \mathrm{H}_{6} \mathrm{~N}_{6} \mathrm{O}_{6}$ & 2,4,6-trinitro-1,3,5-benzenetriamine \\
\hline PBX-9501 & $\begin{array}{c}\text { 95\% HMX, } 2.5 \% \text { Estane }\left(\mathrm{C}_{5.14} \mathrm{H}_{7.50} \mathrm{~N}_{0.19} \mathrm{O}_{1.76}\right)_{\mathrm{n}} \text {, } \\
\text { 2.5\% BDNPA-F }\end{array}$ & -- \\
\hline PBX-9502 & $95 \%$ TATB, 5\% Kel-F 800 & -- \\
\hline NM & $\mathrm{CH}_{3} \mathrm{NO}_{2}$ & Nitromethane \\
\hline ANFO & $95 \%$ Ammonium Nitrate $\left(\mathrm{H}_{4} \mathrm{~N}_{2} \mathrm{O}_{3}\right), 5 \%$ fuel oil & Ammonium nitrate-fuel oil mixture \\
\hline Black Powder & $75 \% \mathrm{KNO}_{3}, 15 \%$ charcoal, $10 \%$ sulfur & -- \\
\hline ТАТР & $\mathrm{C}_{9} \mathrm{H}_{18} \mathrm{O}_{6}$ & Triacetonetriperoxide \\
\hline
\end{tabular}

As can be seen in the tables, the CWM are comprised of a wide variety of elements, making their identification and discrimination relatively simple. Explosives however consist largely of the same elements (carbon, hydrogen, oxygen, and nitrogen) in differing ratios, the major exceptions being the chlorine-bearing explosives LX-17 and PBX-9502, and the non-nitrogenous explosive TATP. The key therefore to explosive identification is in the ability to determine the relative concentrations of the key elements carbon, hydrogen, oxygen, and nitrogen.

In order to examine the feasibility of measuring relative concentrations of these elements, the PGNAA process was studied using MCNP. The results of these calculations were compared with laboratory measurements of simulated explosives using a PINS system. 


\section{MCNP STUDIES}

The geometry of the explosive and detector system modeled with MCNP was relatively simple. The system consisted of a cylinder of explosives, a detector volume, tungsten shielding, and the neutron source with a polyethylene moderator. Examples of these geometries are shown in Figures 2 and 3 . Three neutron sources were used in the calculations: $\mathrm{a}^{252} \mathrm{Cf}$ isotopic neutron source, a DD neutron generator, and a DT neutron generator. The polyethylene moderator is larger for the neutron generator sources in order to accommodate the larger size of a generator tube compared with a Cf source. In most cases, the cylinder of explosives had dimensions such that its diameter was equal to its length. The only exception to this was in the cases where the cylinder was very thin (pancake shaped) or very long (cigar shaped) in order to examine the effects of explosive geometry. The explosives were located $10-\mathrm{cm}$ from the face of the moderator and detector volume.

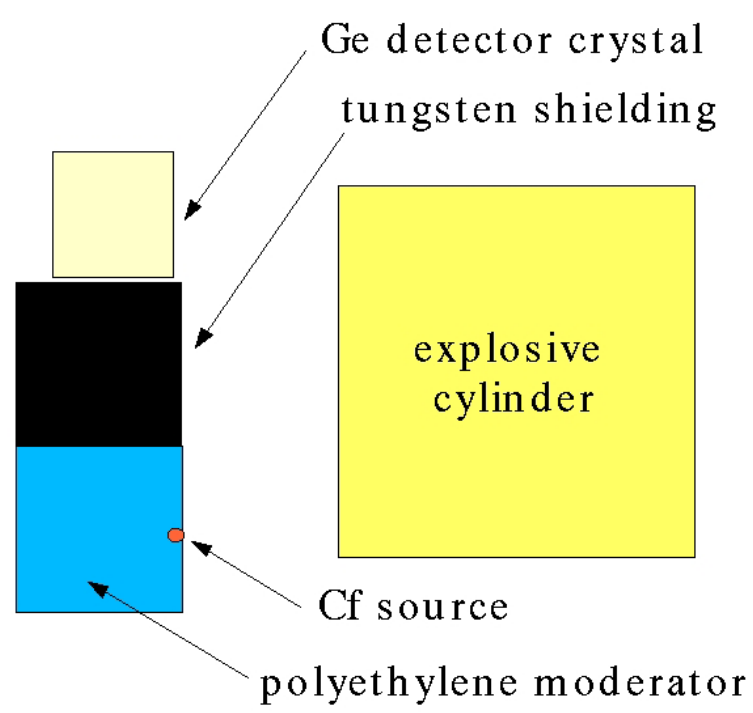

Figure 2. MCNP Geometry for Cf source. 


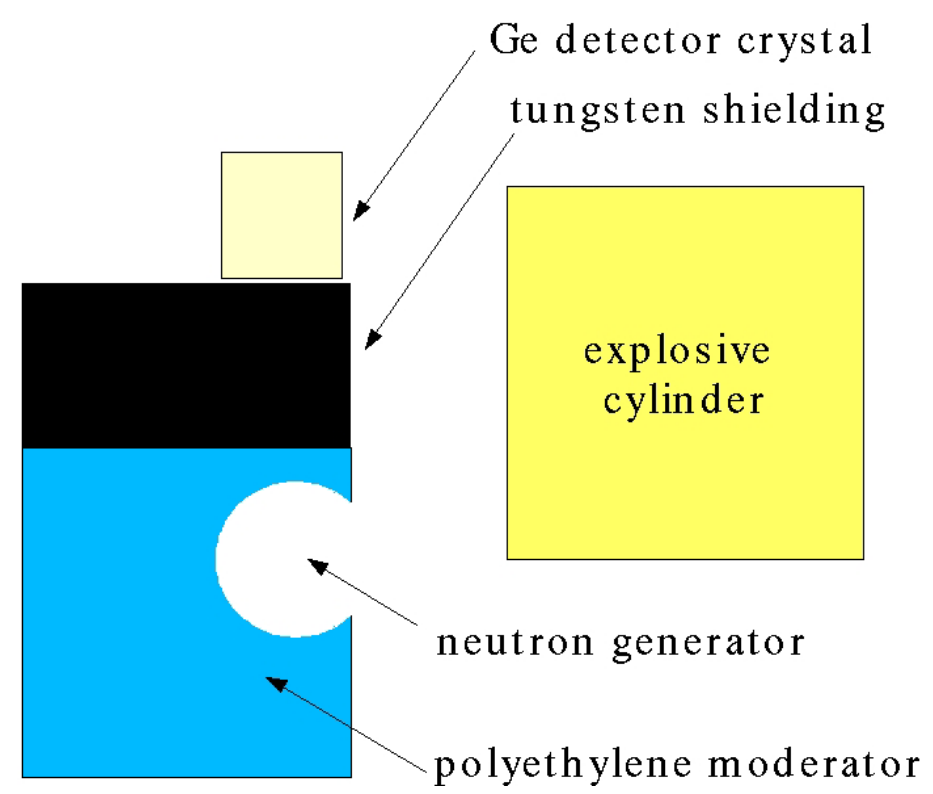

Figure 3. MCNP Geometry for neutron generator sources.

Four masses of explosives were considered in these calculations, 1-kg, 5-kg, 10-kg, and 15-kg. The explosives consisted of those listed in Table 2. The densities and radii of the various cylinders are shown in Table 4.

Table 4. Densities and Dimensions of Explosives.

\begin{tabular}{lccccc}
\hline & $\begin{array}{c}\rho \\
\left(\mathrm{g} / \mathrm{cm}^{3}\right)\end{array}$ & $\begin{array}{c}15-\mathrm{kg} \\
\text { radius }\end{array}$ & $\begin{array}{c}10-\mathrm{kg} \\
\text { radius }\end{array}$ & $\begin{array}{c}5-\mathrm{kg} \\
\text { radius }\end{array}$ & $\begin{array}{c}1-\mathrm{kg} \\
\text { radius }\end{array}$ \\
\hline HMX & 1.903 & 10.79 & 9.42 & 7.48 & 4.37 \\
LX-17 & 1.915 & 10.76 & 9.4 & 7.46 & 4.36 \\
TNT & 1.654 & 11.3 & 9.87 & 7.84 & 4.58 \\
Comp. B & 1.710 & 11.18 & 9.76 & 7.75 & 4.53 \\
TATB & 1.938 & 10.72 & 9.36 & 7.43 & 4.35 \\
PBX-9501 & 1.840 & 10.91 & 9.53 & 7.56 & 4.42 \\
PBX-9502 & 1.900 & 10.79 & 9.43 & 7.48 & 4.38 \\
NM & 1.130 & 12.82 & 11.2 & 8.89 & 5.2 \\
ANFO & 1.750 & 11.09 & 9.69 & 7.69 & 4.5 \\
Black Powder & 1.650 & 11.31 & 9.88 & 7.84 & 4.59 \\
TATP & 1.200 & 12.58 & 10.99 & 8.72 & 5.1 \\
\hline
\end{tabular}

The MCNP calculations were initially carried out on the 15-kg explosive geometries using the DT, $\mathrm{DD}$, and ${ }^{252} \mathrm{Cf}$ neutron sources. The DT neutron source consisted of $14-\mathrm{MeV}$ neutrons that were 
moderated somewhat by the polyethylene block. The DD neutron source consisted of 2.5-MeV neutrons that were also moderated. After examining the results of these initial calculations it was determined that the DD neutron source would not be useful in this application. This is due to the small neutron capture cross-sections of oxygen and carbon. The only neutron reaction with carbon and oxygen that contributes readily measurable gamma rays is neutron scattering. The neutron scattering reaction requires $4.4 \mathrm{MeV}$ neutrons for carbon and $6.1 \mathrm{MeV}$ neutrons for oxygen. Both the ${ }^{252} \mathrm{Cf}$ and the DT sources provide neutrons of these and higher energies.

The results of the MCNP simulations in the form of gamma flux per source neutron can be found in Appendix A. In addition to calculations with explosives, background calculations were performed with only the neutron source and moderator block. The results of these calculations were subtracted from the results with explosives. From these results ratios of gamma ray peaks were calculated and a table showing the ratios for the 15-kg explosive masses is shown in Table 4. Ratios for the other masses are shown in Appendix B. These results are also shown graphically in Figures 4 and 5.

The hydrogen to nitrogen ratio was calculated using the values of the $2223 \mathrm{keV}$ and $10.8 \mathrm{MeV}$ gamma ray peak intensities from MCNP. Both of these gammas-rays result from thermal neutron capture. Taking the ratio of these intensities rather than using their absolute values should eliminate most of the effects of geometry and explosive mass. Similarly, the carbon to oxygen ratio was calculated using the 4.4 MeV and 6.1 MeV gamma-ray intensities. Both of these gamma rays result from inelastic neutron scattering.

Table 5. Elemental Ratios for 15-kg Explosive Mass.

\begin{tabular}{lllll}
\hline \multicolumn{1}{c}{ Explosive } & H/N-Cf & H/N-DT & C/O-Cf & C/O-DT \\
\hline HMX & $27.5(1.2)$ & $26.2(2.7)$ & $1.75(.09)$ & $0.69(.02)$ \\
LX-17 & $27.83(1.6)$ & $23.6(2.8)$ & $3.73(.18)$ & $1.46(.03)$ \\
TNT & $43.8(2.6)$ & $51.2(7.9)$ & $4.10(.18)$ & $1.59(.03)$ \\
Comp. B & $33.8(1.6)$ & $30.0(2.3)$ & $2.69(.13)$ & $1.05(.02)$ \\
TATB & $28.1(1.4)$ & $23.6(1.7)$ & $3.47(.17)$ & $1.38(.03)$ \\
PBX-9501 & $33.2(1.5)$ & $30.6(2.2)$ & $1.93(.09)$ & $0.75(.02)$ \\
PBX-9502 & $28.2(1.5)$ & $25.1(2.1)$ & $3.61(.18)$ & $1.43(.03)$ \\
NM & $87.1(2.9)$ & $84.7(6.4)$ & $1.71(.06)$ & $0.68(.01)$ \\
ANFO & $62.3(1.6)$ & $59.8(3.3)$ & $0.23(.01)$ & $0.08(.002)$ \\
Black Powder & $0.51(0.07)$ & $1.65(0.42)$ & $1.24(.05)$ & $0.46(.01)$ \\
TATP & - & -- & $4.95(.16)$ & $2.06(.04)$ \\
\hline
\end{tabular}




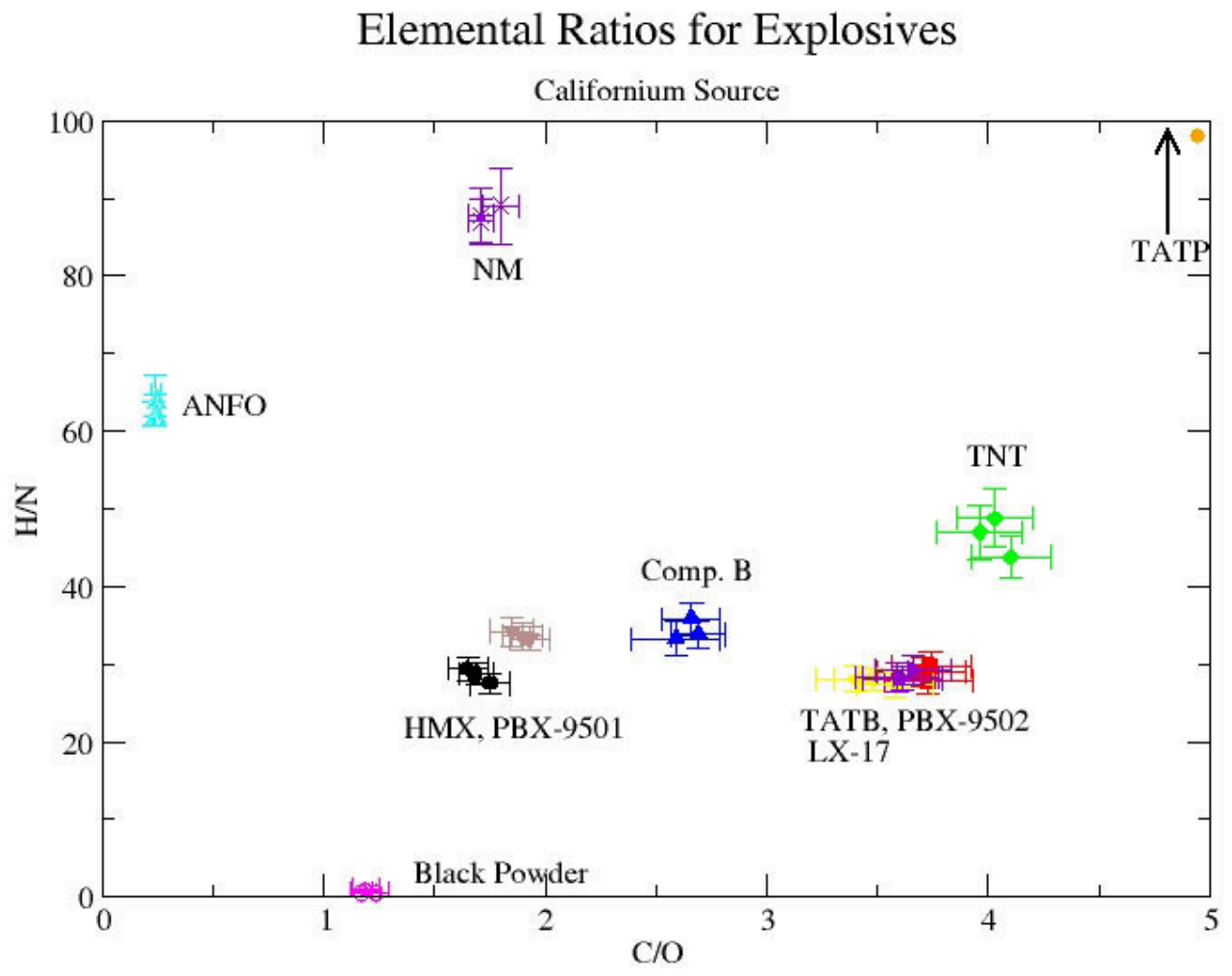

Figure 4. Elemental ratios for Cf source.

\section{Elemental Ratios for Explosives}

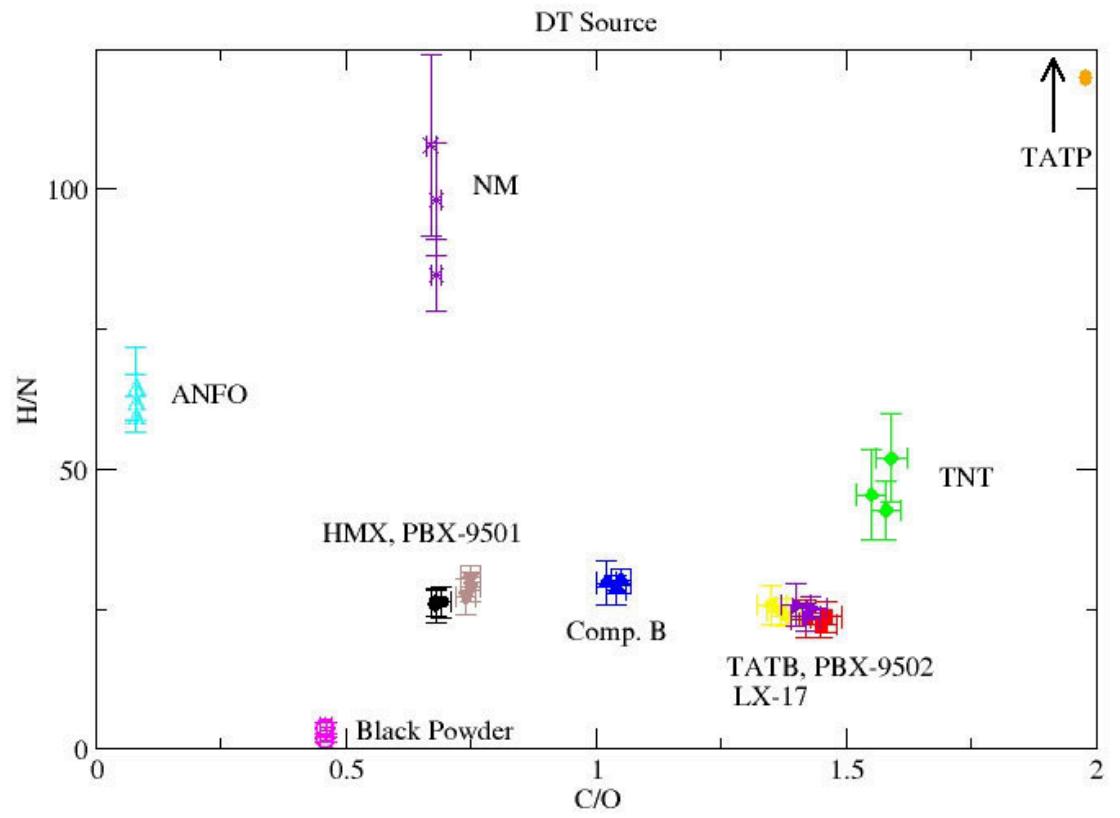

Figure 5. Elemental Ratios for DT source. 
As can be seen in the tables and figures, the ratio of the hydrogen peak area to the nitrogen peak area is consistent both between the californium source and DT generator as well as across the range of explosive mass for any given explosive. The only exception to this is in the case of black powder. This is to be expected, as black powder has no intrinsic hydrogen and all the hydrogen gamma rays observed in the region of the detector are from the polyethylene moderator.

The ratio of the carbon peak area to that of oxygen is consistent across the range of explosive mass for a given neutron source and explosive, but not between the two different neutron sources. These gamma rays are produced by neutron scattering, and the differing energy distributions of the two neutron sources causes the difference in the ratios. The ratio of the carbon-to-oxygen ratio of the two neutron sources is consistent.

As can be seen in the figures, the ratios of hydrogen to nitrogen and carbon to oxygen allow one to readily distinguish most explosives, in particular when the DT neutron generator source is used. It is difficult however to distinguish HMX from PBX-9501 and LX-17 from PBX-9502. TATB can be distinguished from LX-17 and PBX-9502 because the latter both contain chlorine, which is readily detectable. TATP can be distinguished from the rest of the explosives both from the fact that it contains no nitrogen, and from its high carbon-to-oxygen ratio.

In addition to examining the simple cylindrical geometries described above, two additional geometries were studied for each explosive. One of these was a large-diameter thin cylinder as shown in Figure 6. The second was a small-diameter long cylinder as shown in Figure 7. These are described as 'pancake' and 'cigar' shapes. A 15-kg mass of explosive was used in each calculation. Table 5 shows the results for the calculations for the DT neutron source. The results for the Cf source are shown in Appendix B.

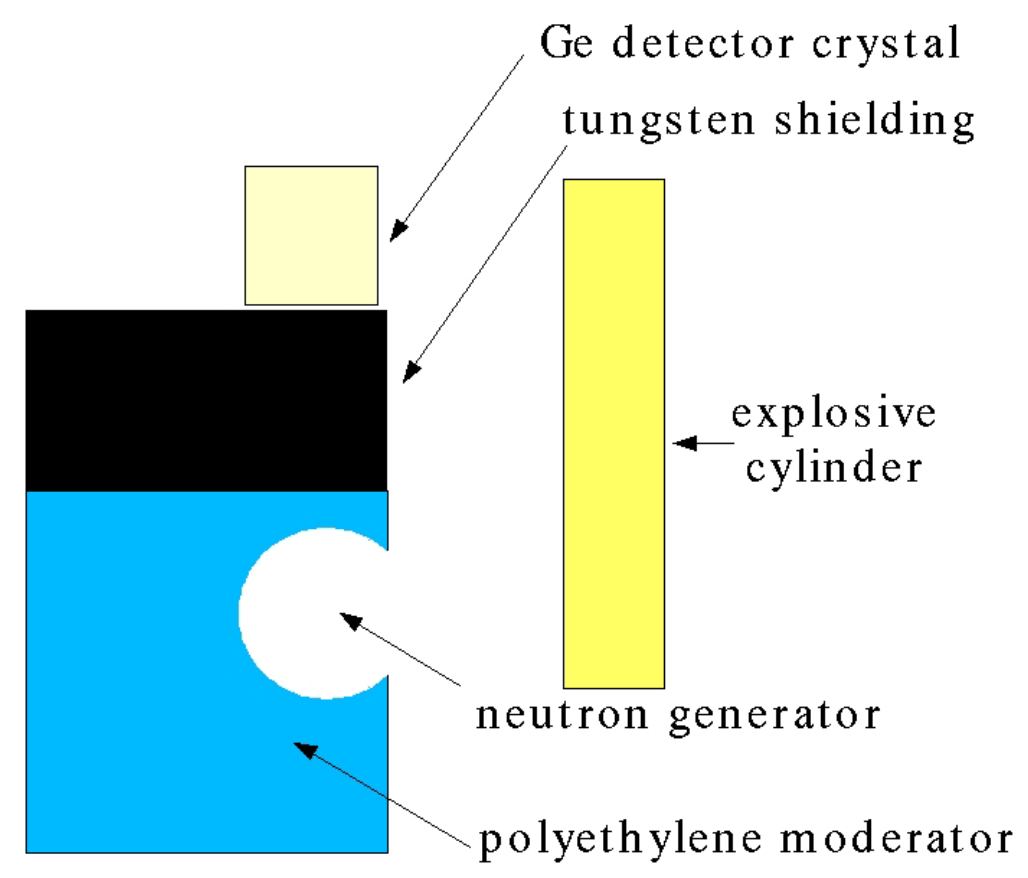

Figure 6. MCNP Geometry for "pancake” shape. 


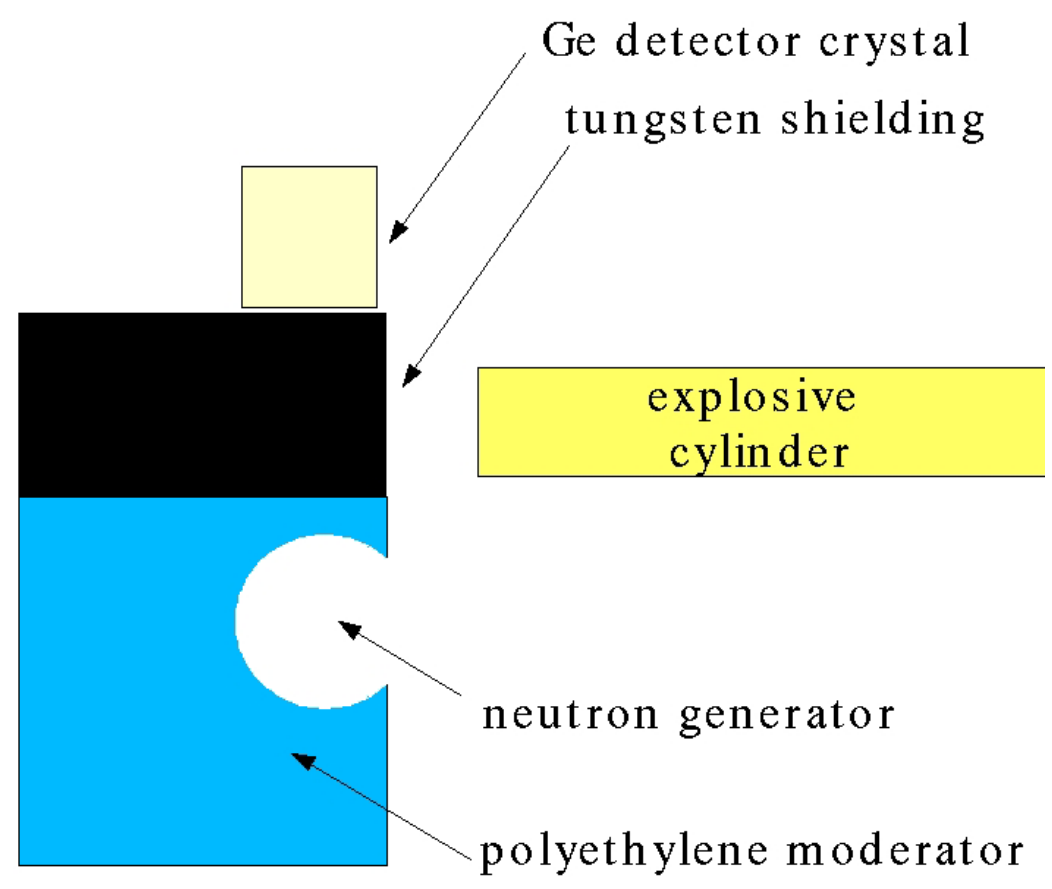

Figure 7. MCNP Geometry for "cigar" shape.

Table 6. DT geometry effects.

\begin{tabular}{lcccccc}
\hline \multicolumn{1}{c}{ Explosive } & H/N-DT & H/N pancake & H/N cigar & C/O-DT & C/O pancake & C/O cigar \\
\hline HMX & $26.2(2.7)$ & $30.6(2.6)$ & $26.0(4)$ & $0.69(0.02)$ & $0.67(0.01)$ & $0.67(0.02)$ \\
LX-17 & $23.6(2.8)$ & $30.9(3.1)$ & $24.7(4)$ & $1.46(0.03)$ & $1.44(0.03)$ & $1.41(0.03)$ \\
TNT & $51.2(7.9)$ & $48.7(5.9)$ & $34.3(7)$ & $1.59(0.03)$ & $1.58(0.03)$ & $1.54(0.03)$ \\
Comp. B & $30.0(2.3)$ & $41.0(4.1)$ & $34.0(6)$ & $1.05(0.02)$ & $1.03(0.02)$ & $1.01(0.02)$ \\
TATB & $23.6(1.7)$ & $29.6(2.7)$ & $30.4(5)$ & $1.38(0.03)$ & $1.36(0.03)$ & $1.34(0.03)$ \\
PBX-9501 & $30.6(2.2)$ & $34.0(3.2)$ & $33.3(5)$ & $0.75(0.02)$ & $0.74(0.01)$ & $0.73(0.02)$ \\
PBX-9502 & $25.1(2.1)$ & $31.8(3.2)$ & $28.1(5)$ & $1.43(0.03)$ & $1.41(0.03)$ & $1.39(0.03)$ \\
NM & $84.7(6.4)$ & $106(13)$ & $99.5(18)$ & $0.68(0.01)$ & $0.67(0.01)$ & $0.67(0.02)$ \\
ANFO & $59.8(3.3)$ & $67.2(4.8)$ & $60.3(7)$ & $0.08(0.002)$ & $0.08(0.002)$ & $0.08(0.002)$ \\
Black Powder & $1.65(0.4)$ & $2.8(0.62)$ & $2.91(1.2)$ & $0.46(0.01)$ & $0.47(0.01)$ & $0.45(0.01)$ \\
TATP & -- & -- & $-1.06(0.04)$ & -- & - \\
\hline
\end{tabular}

As can be seen in the tables, there is very little effect from gross changes in geometry. The ratios of hydrogen to nitrogen and carbon to oxygen are in agreement within the uncertainties for the entire range of explosives as shown in Figure 8 where the hydrogen to nitrogen ratio is plotted versus the carbon to oxygen ratio for the 15-kg cylinder, 15-kg "pancake", and 15-kg "cigar" shaped explosives. 


\section{Elemental Ratios for Explosives}

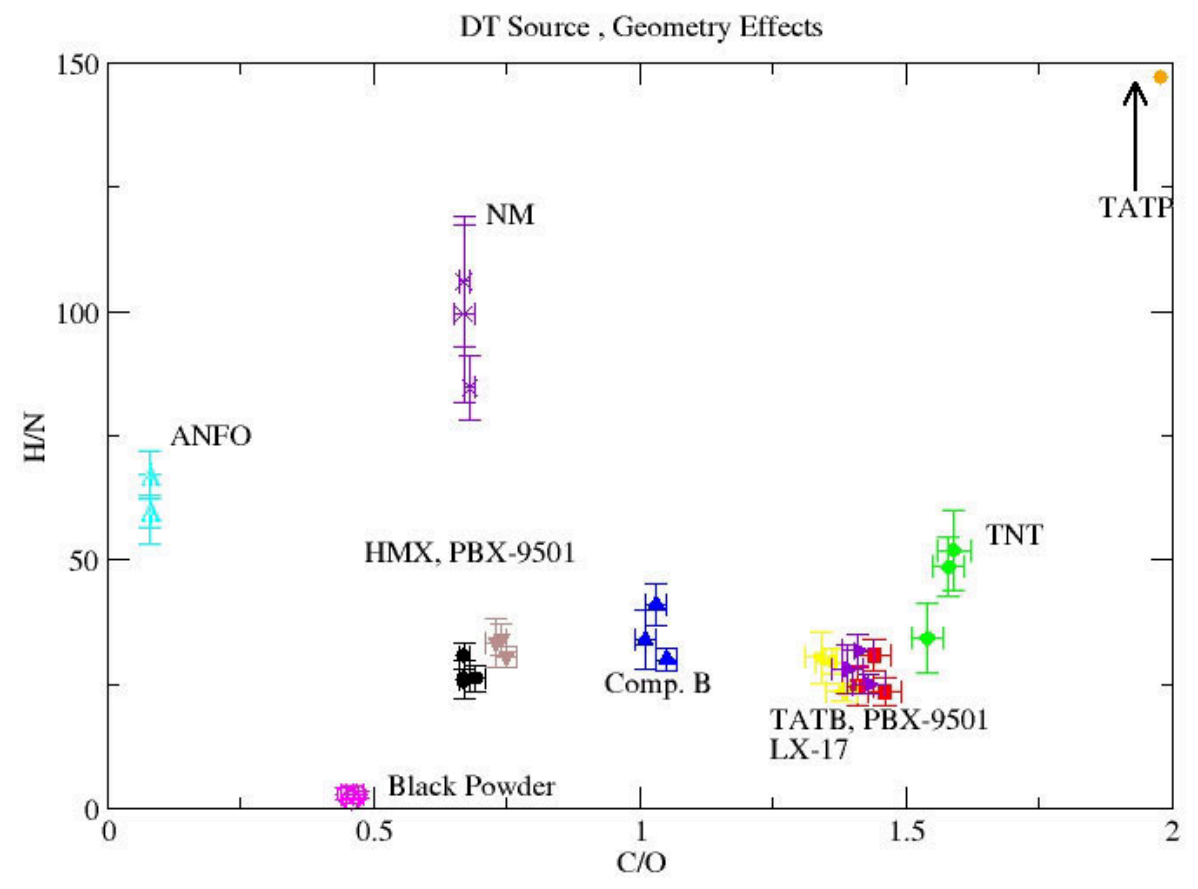

Figure 8. Geometry Effects.

In addition to merely changing the geometry of the explosives, the composition of the system was changed by adding a plug of uranium in the center of the explosive mass. A 10-kg mass of HMX surrounding a $10-\mathrm{kg}$ uranium plug was simulated. The elemental ratios for the $\mathrm{Cf}$ and DT sources are shown in Table 6. As can be seen in the table, the presence of the uranium did not appreciably affect the elemental ratios.

Table 7. DT Geometry Effects with Uranium Plug.

\begin{tabular}{lllll}
\multicolumn{1}{c}{ Explosive } & H/N -Cf & H/N-DT & C/O-DT & C/O -Cf \\
\hline HMX-10kg & $29.4(1.6)$ & $26.0(2.3)$ & $0.68(.01)$ & $1.65(.09)$ \\
HMX 10-kg w/uranium & $28.5(1.7)$ & $25.5(2.8)$ & $0.69(.01)$ & $1.74(.06)$ \\
\hline
\end{tabular}




\section{PINS MEASUREMENTS AND COMPARISON WITH MCNP}

In order to compare with calculation, measurements were performed on explosive simulants of HMX, LX-17, and COMP. B. The elemental composition of the actual explosives and their simulants are shown in Table 7. The simulants were composed of innocuous materials such as melamine, graphite and salt in order to obtain elemental compositions close to that of the actual explosives. The densities of the simulants were significantly lower than the actual explosives however, on the order of $1.0 \mathrm{~g} / \mathrm{cc}$ as opposed to $1.9 \mathrm{~g} / \mathrm{cc}$.

Table 8. Elemental Composition of Explosives and Simulants in weight percent.

\begin{tabular}{lcccccc} 
& HMX & HMX Simulant & LX-17 & LX-17 Simulant & Comp. B & Comp. B Simulant \\
\hline $\mathrm{H}$ & 2.7 & 5 & 2.2 & 4.7 & 2.7 & 5.5 \\
$\mathrm{C}$ & 16.2 & 20.4 & 27.5 & 27.9 & 24.3 & 24.9 \\
$\mathrm{O}$ & 43.2 & 35 & 34.4 & 30 & 42.6 & 39 \\
$\mathrm{~N}$ & 37.8 & 34.6 & 30.1 & 30.2 & 30.4 & 30.2 \\
$\mathrm{Cl}$ & -- & -- & 1.9 & 1.8 & -- & -- \\
$\mathrm{Na}$ & -- & 4.1 & -- & 1.2 & -- & -- \\
$\mathrm{F}$ & -- & -- & -- & 3.8 & -- & - \\
\hline
\end{tabular}

The experimental setup of the measurements effectively duplicated that of the MCNP modeling. Fourteen kilograms of explosive simulant were used in each measurement and a DT generator was used as the neutron source. Gamma-ray spectra were measured with a high -purity germanium detector (HPGe). Measurements were not performed using ${ }^{252} \mathrm{Cf}$ as a source due to its relatively weak excitation of carbon and oxygen.

Gamma ray peak areas were extracted from the gamma spectra of each explosive simulant as well as from a background measurement. The background measurement was performed for one-third the live time of the simulant measurements. The peak areas after background subtraction are shown in Table 8 . The area for hydrogen peak was extracted from the $2223 \mathrm{keV}$ peak, carbon from the $4439 \mathrm{keV}$ peak, oxygen from the $6129 \mathrm{keV}$ peak area, and nitrogen from the sum of the $10829 \mathrm{keV}$ and its first escape peak at $10318 \mathrm{eV}$, and chlorine from the $1164 \mathrm{keV}$ peak.

Table 9. Measured peak areas.

\begin{tabular}{lllll}
\hline & Background & HMX Simulant & LX-17 Simulant & Comp. B Simulant \\
\hline $\mathrm{H}$ & $5834(100)$ & $41561(210)$ & $45321(213)$ & $67995(261)$ \\
$\mathrm{C}$ & 0 & $2779(555)$ & $4360(870)$ & $4068(814)$ \\
$\mathrm{O}$ & $1146(40)$ & $3304(91)$ & $3865(94)$ & $4065(96)$ \\
$\mathrm{N}$ & 0 & $315(17)$ & $312(18)$ & $399(20)$ \\
$\mathrm{Cl}$ & 0 & 0 & $6235(436)$ & 0 \\
\hline
\end{tabular}


The areas for the carbon peak at $4439 \mathrm{keV}$ have relatively large uncertainties. This is due to doppler broadening. The carbon nucleus will de-excite and emit the gamma ray while in flight from neutron scattering and cause a very broad peak to appear in the gamma-ray spectrum.

Additional MCNP calculations were performed, using the compositions and densities of the explosive simultants rather than those of the actual explosives. The results of these calculations are compared with the experimental results in Table 9 and graphically in Figure 9. An overall normalization was performed on the experimental results in order to account for the detector efficiency.

Table 10. Calculated ratios versus measured.

\begin{tabular}{ccccccc}
\hline Ratio & HMX MCNP & $\begin{array}{c}\text { HMX } \\
\text { measured }\end{array}$ & $\begin{array}{c}\text { LX-17 } \\
\text { MCNP }\end{array}$ & $\begin{array}{c}\text { LX-17 } \\
\text { measured }\end{array}$ & $\begin{array}{c}\text { Comp. B } \\
\text { MCNP }\end{array}$ & $\begin{array}{c}\text { Comp. B } \\
\text { measured }\end{array}$ \\
\hline $\mathrm{H} / \mathrm{N}$ & $55.4(3.4)$ & $53.1(3.2)$ & $60.1(4.8)$ & $58.4(3.6)$ & $64.0(4.5)$ & $68.5(4.2)$ \\
$\mathrm{C} / \mathrm{O}$ & $1.07(0.02)$ & $1.1(0.2)$ & $1.7(0.04)$ & $1.47(0.15)$ & $1.18(0.08)$ & $1.31(0.21)$ \\
\hline
\end{tabular}

\section{Elemental Ratios for Simulants}

DT Source, Measured and Calculated

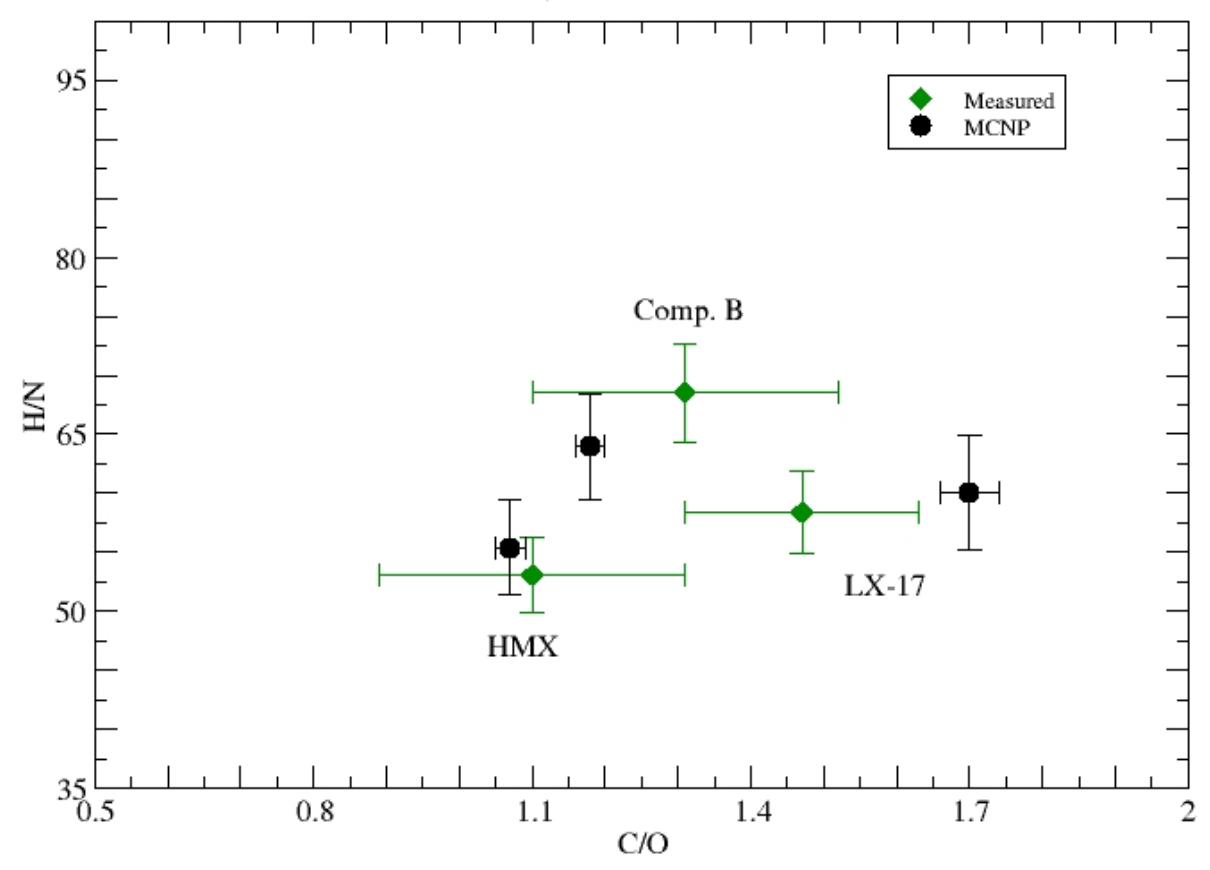

Figure 9. Measured results compared with MCNP.

As can be seen in the table and figure, there is good agreement between the calculated and measured values of the ratios. The $\mathrm{H} / \mathrm{N}$ ratios are in better agreement than the $\mathrm{C} / \mathrm{O}$ ratios. This is to be expected with the relatively high uncertainty in the measured carbon peak areas. 


\section{FUTURE WORK}

The study reported here shows that the PGNAA technique is very suitable for determining the type of explosive found in an improvised nuclear device. Future work will optimize details of both the measurement techniques and analysis of the gamma spectra.

For example, by sorting gamma-ray counts into separate section of memory by gating the multichannel analyzer with respect to the neutron generator pulses, one should reduce the background, and hence, uncertainty in the spectra, especially the carbon peak. (The measurements carried out in FY2004 were performed without time gating of the data acquisition system.) The spectra taken during a generator pulse would be dominated by gamma rays produced by neutron inelastic scattering, e.g. those from carbon and oxygen. The spectra recorded between pulses would be dominated by gamma rays from neutron capture reactions, e.g. those from chlorine, hydrogen, and nitrogen. The net result would be a decrease in the uncertainties of the elemental ratios, particularly the carbon to oxygen ratio.

Measurements of actual explosives will benchmark the Monte Carlo estimates of their elemental gamma-ray intensity ratios. We will also develop an analysis algorithm based on linear discriminant analysis that identifies the explosive present, if any, and determines the identification confidence level. 


\section{CONCLUSIONS}

The use of the PGNAA techniques to measure elemental ratios allows a large degree of discrimination among various types of explosives. Of the eleven explosives examined in this study, five can be distinguished from the others by measuring the hydrogen to nitrogen ratio. These five are ANFO, nitromethane, TATP, TNT, and black powder. Black powder can also be distinguished from the others by the presence of sulfur and potassium, chemical elements absent from other explosives.

The remaining explosives can be largely distinguished by measuring the carbon to oxygen ratio and whether or not chlorine is present. The two chlorine-containing explosives PBX-9502 and LX-17 can be readily distinguished from the rest by measuring the easily detectable chlorine gamma rays. These two explosives share a similar carbon to oxygen ratio with TATB and therefore allow it to be identified by this value combined with a lack of chlorine.

The only explosives that are difficult to distinguish are therefore PBX-9501 from HMX and PBX9502 from LX-17. This is to be expected as PBX-9501 is comprised of 95\% HMX plus a plasticizer, and both PBX-9502 and LX-17 are based on TATB plus plasticizers.

In summary, our Monte Carlo and laboratory studies indicate that PGNAA is indeed a suitable tool to detect and identify explosives, if present, in a suspect improvised nuclear device. 


\section{REFERENCES}

1. A.J. Caffrey, et al., "Chemical Warfare Agent and High Explosive Identification by Spectroscopy of Neutron-Induced Gamma Rays," IEEE Transactions on Nuclear Science 39, p. 1422-1426 (1992).

2. X-5 Monte Carlo Team, "MCNP-A General Monte Carlo N-Particle Transport Code, Version 5," Los Alamos National Laboratory report LA-UR-03-1987 (2003).

3. A.J. Caffrey et al., "U.S. Army Experience with the PINS Chemical Assay System," Idaho National Engineering Laboratory report EGG-NRP-1143 (1994).

4. S. Budavari, ed., The Merck Index, Eleventh Edition (Rahway, N.J.: Merck \& Co., Inc., 1989).

5. B. M. Dobratz, LLNL Explosives Handbook UCRL-52997, 1981. 
Appendix A

MCNP Output 


\section{Appendix A}

MCNP Output

\begin{tabular}{lrrrrrrrrrrr}
\multicolumn{2}{l}{ 252-Cf Source, gamma flux at detector location } & & & & & & & \\
\multicolumn{1}{c}{ Explosive } & H-2223 & Unc & C-4451 & Unc & N-10829 & Unc & O-6129 & Unc & Cl-1165 & Unc \\
\hline HMX & $2.90 \mathrm{E}-007$ & 0.008 & $2.19 \mathrm{E}-008$ & 0.030 & $1.05 \mathrm{E}-008$ & .043 & $1.24 \mathrm{E}-008$ & 0.040 & $1.46 \mathrm{E}-009$ & 0.120 \\
LX-17 & $1.87 \mathrm{E}-007$ & 0.010 & $3.82 \mathrm{E}-008$ & 0.023 & $6.64 \mathrm{E}-009$ & .055 & $1.02 \mathrm{E}-008$ & 0.044 & $4.53 \mathrm{E}-008$ & 0.021 \\
TNT & $2.46 \mathrm{E}-007$ & 0.009 & $5.19 \mathrm{E}-008$ & 0.019 & $5.55 \mathrm{E}-009$ & .059 & $1.26 \mathrm{E}-008$ & 0.040 & $1.67 \mathrm{E}-009$ & 0.115 \\
COMP. B & $2.90 \mathrm{E}-007$ & 0.008 & $3.37 \mathrm{E}-008$ & 0.024 & $8.52 \mathrm{E}-009$ & .048 & $1.24 \mathrm{E}-008$ & 0.040 & $1.61 \mathrm{E}-009$ & 0.118 \\
TATB & $2.43 \mathrm{E}-007$ & 0.009 & $3.85 \mathrm{E}-008$ & 0.023 & $8.55 \mathrm{E}-009$ & .047 & $1.10 \mathrm{E}-008$ & 0.042 & $1.54 \mathrm{E}-009$ & 0.118 \\
PB-9501 & $3.25 \mathrm{E}-007$ & 0.008 & $2.42 \mathrm{E}-008$ & 0.028 & $9.71 \mathrm{E}-009$ & .045 & $1.24 \mathrm{E}-008$ & 0.040 & $1.48 \mathrm{E}-009$ & 0.119 \\
PB-9502 & $2.00 \mathrm{E}-007$ & 0.010 & $3.78 \mathrm{E}-008$ & 0.023 & $7.02 \mathrm{E}-009$ & .053 & $1.04 \mathrm{E}-008$ & 0.043 & $3.46 \mathrm{E}-008$ & 0.024 \\
NM & $7.78 \mathrm{E}-007$ & 0.004 & $2.43 \mathrm{E}-008$ & 0.020 & $8.91 \mathrm{E}-009$ & .033 & $1.41 \mathrm{E}-008$ & 0.026 & $1.95 \mathrm{E}-009$ & 0.077 \\
Anfo & $9.33 \mathrm{E}-007$ & 0.003 & $3.66 \mathrm{E}-009$ & 0.052 & $1.49 \mathrm{E}-008$ & .026 & $1.51 \mathrm{E}-008$ & 0.026 & $2.05 \mathrm{E}-009$ & 0.075 \\
Black Powder & $2.71 \mathrm{E}-009$ & 0.060 & $1.49 \mathrm{E}-008$ & 0.026 & $7.17 \mathrm{E}-010$ & .117 & $1.19 \mathrm{E}-008$ & 0.029 & $1.40 \mathrm{E}-009$ & 0.090 \\
TATP & $2.74 \mathrm{E}-006$ & 0.002 & $5.31 \mathrm{E}-008$ & 0.014 & 0 & & .000 & $1.07 \mathrm{E}-008$ & 0.030 & $2.57 \mathrm{E}-009$ & 0.067 \\
\hline
\end{tabular}

10-KG

\begin{tabular}{lrrrrrrrrrrr}
\hline \multicolumn{1}{c}{ Explosive } & H-2223 & & C-4451 & & N-10829 & & O-6129 & & Cl-1165 \\
\hline HMX & $2.12 \mathrm{E}-007$ & 0.010 & $1.77 \mathrm{E}-008$ & 0.033 & $7.15 \mathrm{E}-009$ & .052 & $1.06 \mathrm{E}-008$ & 0.043 & $1.45 \mathrm{E}-009$ & 0.124 \\
LX-17 & $1.37 \mathrm{E}-007$ & 0.012 & $3.14 \mathrm{E}-008$ & 0.025 & $4.66 \mathrm{E}-009$ & .065 & $8.45 \mathrm{E}-009$ & 0.048 & $3.41 \mathrm{E}-008$ & 0.024 \\
TNT & $1.72 \mathrm{E}-007$ & 0.011 & $4.26 \mathrm{E}-008$ & 0.022 & $3.62 \mathrm{E}-009$ & .074 & $1.07 \mathrm{E}-008$ & 0.043 & $1.78 \mathrm{E}-009$ & 0.115 \\
COMP. B & $2.11 \mathrm{E}-007$ & 0.010 & $2.76 \mathrm{E}-008$ & 0.027 & $5.77 \mathrm{E}-009$ & .058 & $1.06 \mathrm{E}-008$ & 0.043 & $1.56 \mathrm{E}-009$ & 0.120 \\
TATB & $1.74 \mathrm{E}-007$ & 0.011 & $3.13 \mathrm{E}-008$ & 0.025 & $6.15 \mathrm{E}-009$ & .057 & $9.15 \mathrm{E}-009$ & 0.046 & $1.47 \mathrm{E}-009$ & 0.123 \\
PB-9501 & $2.39 \mathrm{E}-007$ & 0.009 & $1.98 \mathrm{E}-008$ & 0.031 & $6.91 \mathrm{E}-009$ & .053 & $1.06 \mathrm{E}-008$ & 0.043 & $1.55 \mathrm{E}-009$ & 0.120 \\
PB-9502 & $1.47 \mathrm{E}-007$ & 0.012 & $3.15 \mathrm{E}-008$ & 0.025 & $5.13 \mathrm{E}-009$ & .062 & $8.73 \mathrm{E}-009$ & 0.047 & $2.60 \mathrm{E}-008$ & 0.028 \\
NM & $5.59 \mathrm{E}-007$ & 0.004 & $2.03 \mathrm{E}-008$ & 0.022 & $6.34 \mathrm{E}-009$ & .039 & $1.18 \mathrm{E}-008$ & 0.029 & $1.73 \mathrm{E}-009$ & 0.082 \\
Anfo & $6.99 \mathrm{E}-007$ & 0.004 & $3.09 \mathrm{E}-009$ & 0.056 & $1.11 \mathrm{E}-008$ & .030 & $1.23 \mathrm{E}-008$ & 0.028 & $1.82 \mathrm{E}-009$ & 0.081 \\
Black Powder & $2.61 \mathrm{E}-009$ & 0.062 & $1.20 \mathrm{E}-008$ & 0.029 & $5.37 \mathrm{E}-010$ & .134 & $1.01 \mathrm{E}-008$ & 0.031 & $1.30 \mathrm{E}-009$ & 0.093 \\
TATP & $2.01 \mathrm{E}-006$ & 0.002 & $4.36 \mathrm{E}-008$ & 0.015 & $0.00 \mathrm{E}+000$ & .000 & $8.84 \mathrm{E}-009$ & 0.034 & $2.27 \mathrm{E}-009$ & 0.071 \\
\hline
\end{tabular}




\begin{tabular}{|c|c|c|c|c|c|c|c|c|c|c|}
\hline \multicolumn{11}{|l|}{ 5-KG } \\
\hline Explosive & H-2223 & & C-4451 & & N-10829 & & O-6129 & & Cl-1165 & \\
\hline HMX & $1.16 \mathrm{E}-007$ & 0.009 & $1.21 \mathrm{E}-008$ & 0.029 & 3.97E-009 & .050 & 7.07E-009 & 0.037 & $1.27 \mathrm{E}-009$ & 0.097 \\
\hline LX-17 & 7.56E-008 & 0.011 & $2.13 \mathrm{E}-008$ & 0.022 & $2.47 \mathrm{E}-009$ & .064 & $5.65 \mathrm{E}-009$ & 0.042 & $2.01 \mathrm{E}-008$ & 0.023 \\
\hline TNT & $9.04 \mathrm{E}-008$ & 0.010 & $2.90 \mathrm{E}-008$ & 0.019 & $1.81 \mathrm{E}-009$ & .075 & $7.15 \mathrm{E}-009$ & 0.037 & $1.28 \mathrm{E}-009$ & 0.096 \\
\hline COMP. B & $1.12 \mathrm{E}-007$ & 0.009 & $1.84 \mathrm{E}-008$ & 0.023 & $3.07 \mathrm{E}-009$ & .057 & 6.87E-009 & 0.038 & $1.25 \mathrm{E}-009$ & 0.097 \\
\hline TATB & $9.51 \mathrm{E}-008$ & 0.010 & $2.16 \mathrm{E}-008$ & 0.022 & $3.39 \mathrm{E}-009$ & .054 & 5.97E-009 & 0.041 & $1.23 \mathrm{E}-009$ & 0.097 \\
\hline PB-9501 & $1.30 \mathrm{E}-007$ & 0.009 & $1.35 \mathrm{E}-008$ & 0.027 & $3.81 \mathrm{E}-009$ & .051 & $6.97 \mathrm{E}-009$ & 0.038 & $1.32 \mathrm{E}-009$ & 0.094 \\
\hline PB-9502 & $8.00 \mathrm{E}-008$ & 0.011 & $2.15 \mathrm{E}-008$ & 0.022 & $2.66 \mathrm{E}-009$ & .061 & $5.81 \mathrm{E}-009$ & 0.041 & $1.51 \mathrm{E}-008$ & 0.026 \\
\hline NM & $2.96 \mathrm{E}-007$ & 0.006 & $1.48 \mathrm{E}-008$ & 0.026 & $3.30 \mathrm{E}-009$ & .055 & $8.10 \mathrm{E}-009$ & 0.035 & $1.40 \mathrm{E}-009$ & 0.091 \\
\hline Anfo & $3.96 \mathrm{E}-007$ & 0.005 & $2.26 \mathrm{E}-009$ & 0.066 & $6.10 \mathrm{E}-009$ & .040 & $8.48 \mathrm{E}-009$ & 0.034 & $1.53 \mathrm{E}-009$ & 0.089 \\
\hline Black Powder & 2.61E-009 & 0.062 & $8.21 \mathrm{E}-009$ & 0.035 & $3.23 \mathrm{E}-010$ & .177 & 6.72E-009 & 0.039 & $1.09 \mathrm{E}-009$ & 0.103 \\
\hline TATP & $1.08 \mathrm{E}-006$ & 0.003 & $3.09 \mathrm{E}-008$ & 0.018 & $0.00 \mathrm{E}+000$ & .000 & $6.08 \mathrm{E}-009$ & 0.041 & $1.74 \mathrm{E}-009$ & 0.081 \\
\hline
\end{tabular}

\begin{tabular}{|c|c|c|c|c|c|c|c|c|c|c|}
\hline \multicolumn{11}{|l|}{ 1-KG } \\
\hline Explosive & H-2223 & & C-4451 & & N-10829 & & O-6129 & & Cl-1165 & \\
\hline HMX & $2.63 \mathrm{E}-008$ & 0.019 & 4.75E-009 & 0.046 & 7.57E-010 & .116 & 2.61E-009 & 0.061 & $9.79 \mathrm{E}-010$ & 0.110 \\
\hline LX-17 & $1.87 \mathrm{E}-008$ & 0.023 & 7.91E-009 & 0.035 & $5.23 \mathrm{E}-010$ & .137 & $2.05 \mathrm{E}-009$ & 0.069 & $5.25 \mathrm{E}-009$ & 0.045 \\
\hline TNT & $2.03 \mathrm{E}-008$ & 0.022 & $1.09 \mathrm{E}-008$ & 0.030 & $3.09 \mathrm{E}-010$ & .179 & $2.51 \mathrm{E}-009$ & 0.062 & $1.09 \mathrm{E}-009$ & 0.105 \\
\hline COMP. B & $2.52 \mathrm{E}-008$ & 0.020 & 7.03E-009 & 0.037 & $5.40 \mathrm{E}-010$ & .133 & $2.55 \mathrm{E}-009$ & 0.062 & $1.02 \mathrm{E}-009$ & 0.108 \\
\hline TATB & $2.23 \mathrm{E}-008$ & 0.021 & $8.10 \mathrm{E}-009$ & 0.035 & $5.50 \mathrm{E}-010$ & .132 & $2.15 \mathrm{E}-009$ & 0.067 & $9.79 \mathrm{E}-010$ & 0.109 \\
\hline PB-9501 & $2.89 \mathrm{E}-008$ & 0.019 & $5.15 \mathrm{E}-009$ & 0.044 & $6.58 \mathrm{E}-010$ & .120 & $2.49 \mathrm{E}-009$ & 0.062 & $1.01 \mathrm{E}-009$ & 0.106 \\
\hline PB-9502 & $1.97 \mathrm{E}-008$ & 0.022 & 8.12E-009 & 0.035 & $5.60 \mathrm{E}-010$ & .133 & 2.09E-009 & 0.068 & 4.06E-009 & 0.051 \\
\hline NM & $5.49 \mathrm{E}-009$ & 0.042 & $5.49 \mathrm{E}-009$ & 0.042 & $6.01 \mathrm{E}-010$ & .128 & $2.88 \mathrm{E}-009$ & 0.058 & $1.05 \mathrm{E}-009$ & 0.105 \\
\hline Anfo & $8.53 \mathrm{E}-008$ & 0.011 & $7.92 \mathrm{E}-010$ & 0.111 & $1.25 \mathrm{E}-009$ & .088 & $3.18 \mathrm{E}-009$ & 0.055 & $1.08 \mathrm{E}-009$ & 0.107 \\
\hline Black Powder & $2.43 \mathrm{E}-009$ & 0.064 & $2.88 \mathrm{E}-009$ & 0.059 & $9.38 \mathrm{E}-011$ & .334 & 2.39E-009 & 0.065 & $9.46 \mathrm{E}-010$ & 0.112 \\
\hline
\end{tabular}

\begin{tabular}{|c|c|c|c|c|c|c|c|c|c|c|}
\hline \multicolumn{11}{|l|}{ Background } \\
\hline Explosive & H-2223 & & C-4451 & & N-10829 & & O-6129 & & Cl-1165 & \\
\hline & 2.34E-009 & 0.064 & $1.90 \mathrm{E}-010$ & 0.229 & 0 & .000 & 0 & 0.000 & $8.50 \mathrm{E}-010$ & 0.119 \\
\hline
\end{tabular}




\begin{tabular}{|c|c|c|c|c|c|c|c|c|c|c|}
\hline Explosive & $\mathrm{H}-2223$ & & C-4451 & & N-10829 & & O-6129 & & $\mathrm{Cl}-1165$ & \\
\hline HMX & $2.37 \mathrm{E}-007$ & 0.006 & $3.47 \mathrm{E}-008$ & 0.017 & 7.69E-009 & .035 & $1.99 \mathrm{E}-008$ & 0.022 & $1.96 \mathrm{E}-009$ & 0.077 \\
\hline LX-17 & $1.60 \mathrm{E}-007$ & 0.008 & $6.03 \mathrm{E}-008$ & 0.013 & 4.81E-009 & .044 & $1.62 \mathrm{E}-008$ & 0.024 & $4.20 \mathrm{E}-008$ & 0.015 \\
\hline TNT & $1.60 \mathrm{E}-007$ & 0.008 & $7.46 \mathrm{E}-008$ & 0.011 & $2.84 \mathrm{E}-009$ & .058 & $1.89 \mathrm{E}-008$ & 0.022 & $2.26 \mathrm{E}-009$ & 0.072 \\
\hline COMP. B & $2.07 \mathrm{E}-007$ & 0.007 & 4.93E-008 & 0.014 & 5.13E-009 & .043 & $1.89 \mathrm{E}-008$ & 0.022 & $2.16 \mathrm{E}-009$ & 0.072 \\
\hline ТАТВ & $1.96 \mathrm{E}-007$ & 0.007 & $6.08 \mathrm{E}-008$ & 0.013 & $6.52 \mathrm{E}-009$ & .038 & $1.76 \mathrm{E}-008$ & 0.023 & $1.94 \mathrm{E}-009$ & 0.075 \\
\hline PB-9501 & $3.52 \mathrm{E}-007$ & 0.005 & $4.17 \mathrm{E}-008$ & 0.015 & $1.00 \mathrm{E}-008$ & .031 & $2.15 \mathrm{E}-008$ & 0.021 & $2.18 \mathrm{E}-009$ & 0.072 \\
\hline PB-9502 & $1.69 \mathrm{E}-007$ & 0.008 & $6.00 \mathrm{E}-008$ & 0.013 & $5.14 \mathrm{E}-009$ & .043 & $1.67 \mathrm{E}-008$ & 0.024 & $3.04 \mathrm{E}-008$ & 0.018 \\
\hline NM & $3.37 \mathrm{E}-007$ & 0.005 & $3.05 \mathrm{E}-008$ & 0.018 & $3.40 \mathrm{E}-009$ & .053 & $1.76 \mathrm{E}-008$ & 0.023 & $2.10 \mathrm{E}-009$ & 0.075 \\
\hline Anfo & $7.70 \mathrm{E}-007$ & 0.004 & $5.49 \mathrm{E}-009$ & 0.041 & $1.13 \mathrm{E}-008$ & .029 & $2.36 \mathrm{E}-008$ & 0.020 & $2.27 \mathrm{E}-009$ & 0.071 \\
\hline Black Powder & $2.81 \mathrm{E}-009$ & 0.059 & $2.05 \mathrm{E}-008$ & 0.022 & $7.28 \mathrm{E}-010$ & .113 & $1.63 \mathrm{E}-008$ & 0.024 & $1.62 \mathrm{E}-009$ & 0.083 \\
\hline TATP & $1.15 \mathrm{E}-006$ & 0.003 & $7.08 \mathrm{E}-008$ & 0.012 & & & $1.42 \mathrm{E}-008$ & 0.026 & & \\
\hline
\end{tabular}

\begin{tabular}{|c|c|c|c|c|c|c|c|c|c|c|}
\hline \multicolumn{11}{|l|}{ 15-KG cigar } \\
\hline Explosive & $\mathrm{H}-2223$ & & C-4451 & & N-10829 & & O-6129 & & $\mathrm{Cl}-1165$ & \\
\hline HMX & 7.53E-008 & 0.012 & $9.20 \mathrm{E}-009$ & 0.033 & $2.53 \mathrm{E}-009$ & .063 & $5.31 \mathrm{E}-009$ & 0.043 & $1.11 \mathrm{E}-009$ & 0.102 \\
\hline LX-17 & $5.08 \mathrm{E}-008$ & 0.014 & $1.59 \mathrm{E}-008$ & 0.025 & $1.69 \mathrm{E}-009$ & .077 & 4.30E-009 & 0.048 & $1.34 \mathrm{E}-008$ & 0.028 \\
\hline TNT & $5.80 \mathrm{E}-008$ & 0.013 & $2.19 \mathrm{E}-008$ & 0.021 & $1.17 \mathrm{E}-009$ & .094 & $5.48 \mathrm{E}-009$ & 0.042 & $1.16 \mathrm{E}-009$ & 0.100 \\
\hline COMP. B & 7.25E-008 & 0.012 & $1.38 \mathrm{E}-008$ & 0.027 & $1.89 \mathrm{E}-009$ & .072 & 5.33E-009 & 0.043 & $1.10 \mathrm{E}-009$ & 0.103 \\
\hline TATB & $6.25 \mathrm{E}-008$ & 0.013 & $1.61 \mathrm{E}-008$ & 0.025 & $2.19 \mathrm{E}-009$ & .068 & 4.71E-009 & 0.046 & $1.05 \mathrm{E}-009$ & 0.104 \\
\hline PB-9501 & $8.44 \mathrm{E}-008$ & 0.011 & $1.01 \mathrm{E}-008$ & 0.031 & $2.44 \mathrm{E}-009$ & .064 & $5.23 \mathrm{E}-009$ & 0.043 & $1.14 \mathrm{E}-009$ & 0.100 \\
\hline PB-9502 & $5.35 \mathrm{E}-008$ & 0.014 & $1.60 \mathrm{E}-008$ & 0.025 & $1.71 \mathrm{E}-009$ & .076 & 4.42E-009 & 0.047 & $1.00 \mathrm{E}-008$ & 0.032 \\
\hline NM & $1.86 \mathrm{E}-007$ & 0.007 & $1.15 \mathrm{E}-008$ & 0.029 & $2.06 \mathrm{E}-009$ & .070 & $6.24 \mathrm{E}-009$ & 0.040 & $1.23 \mathrm{E}-009$ & 0.099 \\
\hline Anfo & 2.61E-007 & 0.006 & $1.70 \mathrm{E}-009$ & 0.075 & $4.05 \mathrm{E}-009$ & .049 & $6.52 \mathrm{E}-009$ & 0.039 & $1.30 \mathrm{E}-009$ & 0.098 \\
\hline Black Powder & $2.57 \mathrm{E}-009$ & 0.062 & $6.27 \mathrm{E}-009$ & 0.040 & $2.34 \mathrm{E}-010$ & .201 & $5.33 \mathrm{E}-009$ & 0.044 & $9.80 \mathrm{E}-010$ & 0.108 \\
\hline TATP & $6.72 \mathrm{E}-007$ & 0.004 & $2.40 \mathrm{E}-008$ & 0.020 & & & 4.83E-009 & 0.046 & & \\
\hline
\end{tabular}




\section{DT Source}

\begin{tabular}{|c|c|c|c|c|c|c|c|c|c|c|}
\hline Explosive & $\mathrm{H}-2223$ & & C-4451 & & N-10829 & & O-6129 & & $\mathrm{Cl}-1165$ & \\
\hline HMX & $6.49 \mathrm{E}-008$ & 0.02 & $2.60 \mathrm{E}-007$ & 0.01 & $2.08 \mathrm{E}-009$ & 0.1 & $3.52 \mathrm{E}-007$ & 0.01 & $5.20 \mathrm{E}-009$ & 0.07 \\
\hline LX-17 & 4.44E-008 & 0.02 & $4.35 \mathrm{E}-007$ & 0.01 & $1.44 \mathrm{E}-009$ & 0.12 & $2.85 \mathrm{E}-007$ & 0.01 & $1.30 \mathrm{E}-008$ & 0.04 \\
\hline TNT & $5.46 \mathrm{E}-008$ & 0.02 & $5.78 \mathrm{E}-007$ & 0.01 & $8.52 \mathrm{E}-010$ & 0.15 & $3.51 \mathrm{E}-007$ & 0.01 & $5.22 \mathrm{E}-009$ & 0.07 \\
\hline COMP. B & $6.38 \mathrm{E}-008$ & 0.01 & $3.83 \mathrm{E}-007$ & 0.01 & $1.78 \mathrm{E}-009$ & 0.08 & $3.49 \mathrm{E}-007$ & 0.01 & $5.32 \mathrm{E}-009$ & 0.05 \\
\hline TATB & $5.62 \mathrm{E}-008$ & 0.01 & $4.41 \mathrm{E}-007$ & 0 & $1.94 \mathrm{E}-009$ & 0.07 & $3.06 \mathrm{E}-007$ & 0.01 & $5.41 \mathrm{E}-009$ & 0.05 \\
\hline PB-9501 & 7.32E-008 & 0.01 & $2.80 \mathrm{E}-007$ & 0.01 & $2.05 \mathrm{E}-009$ & 0.07 & $3.51 \mathrm{E}-007$ & 0.01 & $5.44 \mathrm{E}-009$ & 0.05 \\
\hline PB-9502 & $4.68 \mathrm{E}-008$ & 0.01 & $4.36 \mathrm{E}-007$ & 0 & $1.45 \mathrm{E}-009$ & 0.08 & $2.91 \mathrm{E}-007$ & 0.01 & $1.14 \mathrm{E}-008$ & 0.03 \\
\hline NM & $1.55 \mathrm{E}-007$ & 0.01 & $2.87 \mathrm{E}-007$ & 0.01 & $1.71 \mathrm{E}-009$ & 0.08 & $3.95 \mathrm{E}-007$ & 0.01 & $5.64 \mathrm{E}-009$ & 0.05 \\
\hline Anfo & $2.12 \mathrm{E}-007$ & 0.01 & $5.48 \mathrm{E}-008$ & 0.01 & $3.37 \mathrm{E}-009$ & 0.05 & 4.43E-007 & 0 & $5.56 \mathrm{E}-009$ & 0.05 \\
\hline Black Powder & $1.06 \mathrm{E}-008$ & 0.03 & $1.59 \mathrm{E}-007$ & 0.01 & $1.50 \mathrm{E}-010$ & 0.25 & $3.05 \mathrm{E}-007$ & 0.01 & $5.66 \mathrm{E}-009$ & 0.05 \\
\hline TATP & $6.69 \mathrm{E}-007$ & 0 & $6.68 \mathrm{E}-007$ & 0 & $0.00000 \mathrm{E}$ & 0 & $3.15 \mathrm{E}-007$ & 0.01 & $5.68 \mathrm{E}-009$ & 0.05 \\
\hline
\end{tabular}

\begin{tabular}{lrrrrrrrrrrrr}
\hline 10-KG & & & & & & & & & & \\
\multicolumn{1}{c}{ Explosive } & H-2223 & & C-4451 & & N-10829 & & O-6129 & & Cl-1165 & \\
\hline HMX & $4.74 \mathrm{E}-008$ & 0.01 & $2.11 \mathrm{E}-007$ & 0.01 & $1.42 \mathrm{E}-009$ & 0.08 & $2.82 \mathrm{E}-007$ & 0.01 & $5.32 \mathrm{E}-009$ & 0.05 \\
LX-17 & $3.36 \mathrm{E}-008$ & 0.02 & $3.51 \mathrm{E}-007$ & 0.01 & $1.05 \mathrm{E}-009$ & 0.1 & $2.29 \mathrm{E}-007$ & 0.01 & $1.07 \mathrm{E}-008$ & 0.03 \\
TNT & $3.94 \mathrm{E}-008$ & 0.02 & $4.64 \mathrm{E}-007$ & 0 & $6.82 \mathrm{E}-010$ & 0.12 & $2.83 \mathrm{E}-007$ & 0.01 & $5.35 \mathrm{E}-009$ & 0.05 \\
COMP. B & $4.64 \mathrm{E}-008$ & 0.01 & $3.09 \mathrm{E}-007$ & 0.01 & $1.27 \mathrm{E}-009$ & 0.09 & $2.80 \mathrm{E}-007$ & 0.01 & $5.36 \mathrm{E}-009$ & 0.05 \\
TATB & $4.07 \mathrm{E}-008$ & 0.02 & $3.54 \mathrm{E}-007$ & 0.01 & $1.23 \mathrm{E}-009$ & 0.09 & $2.45 \mathrm{E}-007$ & 0.01 & $5.46 \mathrm{E}-009$ & 0.05 \\
PB-9501 & $5.23 \mathrm{E}-008$ & 0.01 & $2.28 \mathrm{E}-007$ & 0.01 & $1.45 \mathrm{E}-009$ & 0.08 & $2.81 \mathrm{E}-007$ & 0.01 & $5.34 \mathrm{E}-009$ & 0.05 \\
PB-9502 & $3.52 \mathrm{E}-008$ & 0.02 & $3.51 \mathrm{E}-007$ & 0.01 & $1.06 \mathrm{E}-009$ & 0.1 & $2.34 \mathrm{E}-007$ & 0.01 & $9.49 \mathrm{E}-009$ & 0.04 \\
NM & $1.08 \mathrm{E}-007$ & 0.01 & $2.35 \mathrm{E}-007$ & 0.01 & $9.94 \mathrm{E}-010$ & 0.1 & $3.19 \mathrm{E}-007$ & 0.01 & $5.49 \mathrm{E}-009$ & 0.05 \\
Anfo & $1.52 \mathrm{E}-007$ & 0.01 & $4.73 \mathrm{E}-008$ & 0.01 & $2.28 \mathrm{E}-009$ & 0.07 & $3.59 \mathrm{E}-007$ & 0.01 & $5.40 \mathrm{E}-009$ & 0.05 \\
Black Powder & $1.08 \mathrm{E}-008$ & 0.03 & $1.30 \mathrm{E}-007$ & 0.01 & $1.25 \mathrm{E}-010$ & 0.29 & $2.44 \mathrm{E}-007$ & 0.01 & $5.80 \mathrm{E}-009$ & 0.05 \\
TATP & $4.58 \mathrm{E}-007$ & 0 & $5.42 \mathrm{E}-007$ & 0 & $0.00 \mathrm{E}+000$ & 0 & $2.56 \mathrm{E}-007$ & 0.01 & $5.54 \mathrm{E}-009$ & 0.05 \\
\hline
\end{tabular}




\begin{tabular}{lccccccccccc}
\hline 5-KG & & & & & & & & & & & \\
\multicolumn{1}{c}{ Explosive } & H-2223 & & C-4451 & & N-10829 & & O-6129 & & Cl-1165 & \\
\hline HMX & $2.89 \mathrm{E}-008$ & 0.02 & $1.46 \mathrm{E}-007$ & 0.01 & $7.24 \mathrm{E}-010$ & 0.12 & $1.89 \mathrm{E}-007$ & 0.01 & $5.45 \mathrm{E}-009$ & 0.05 \\
LX-17 & $2.17 \mathrm{E}-008$ & 0.02 & $2.36 \mathrm{E}-007$ & 0.01 & $4.87 \mathrm{E}-010$ & 0.14 & $1.53 \mathrm{E}-007$ & 0.01 & $8.18 \mathrm{E}-009$ & 0.04 \\
TNT & $2.43 \mathrm{E}-008$ & 0.02 & $3.12 \mathrm{E}-007$ & 0.01 & $3.08 \mathrm{E}-010$ & 0.17 & $1.89 \mathrm{E}-007$ & 0.01 & $5.55 \mathrm{E}-009$ & 0.05 \\
COMP. B & $2.81 \mathrm{E}-008$ & 0.02 & $2.10 \mathrm{E}-007$ & 0.01 & $5.98 \mathrm{E}-010$ & 0.13 & $1.87 \mathrm{E}-007$ & 0.01 & $5.49 \mathrm{E}-009$ & 0.05 \\
TATB & $2.54 \mathrm{E}-008$ & 0.02 & $2.39 \mathrm{E}-007$ & 0.01 & $5.82 \mathrm{E}-010$ & 0.13 & $1.63 \mathrm{E}-007$ & 0.01 & $5.48 \mathrm{E}-009$ & 0.05 \\
PB-9501 & $3.14 \mathrm{E}-008$ & 0.02 & $1.57 \mathrm{E}-007$ & 0.01 & $7.71 \mathrm{E}-010$ & 0.11 & $1.87 \mathrm{E}-007$ & 0.01 & $5.39 \mathrm{E}-009$ & 0.05 \\
PB-9502 & $2.25 \mathrm{E}-008$ & 0.02 & $2.37 \mathrm{E}-007$ & 0.01 & $4.75 \mathrm{E}-010$ & 0.14 & $1.56 \mathrm{E}-007$ & 0.01 & $7.63 \mathrm{E}-009$ & 0.04 \\
NM & $5.77 \mathrm{E}-008$ & 0.01 & $1.64 \mathrm{E}-007$ & 0.01 & $4.39 \mathrm{E}-010$ & 0.15 & $2.17 \mathrm{E}-007$ & 0.01 & $5.54 \mathrm{E}-009$ & 0.05 \\
Anfo & $8.26 \mathrm{E}-008$ & 0.01 & $3.80 \mathrm{E}-008$ & 0.02 & $1.11 \mathrm{E}-009$ & 0.1 & $2.40 \mathrm{E}-007$ & 0.01 & $5.52 \mathrm{E}-009$ & 0.05 \\
Black Powder & $1.06 \mathrm{E}-008$ & 0.03 & $9.29 \mathrm{E}-008$ & 0.01 & $6.91 \mathrm{E}-011$ & 0.36 & $1.62 \mathrm{E}-007$ & 0.01 & $5.63 \mathrm{E}-009$ & 0.05 \\
TATP & $2.22 \mathrm{E}-007$ & 0.01 & $3.71 \mathrm{E}-007$ & 0.01 & $0.00 \mathrm{E}+000$ & 0 & $1.75 \mathrm{E}-007$ & 0.01 & $5.43 \mathrm{E}-009$ & 0.05 \\
\hline
\end{tabular}

\begin{tabular}{|c|c|c|c|c|c|c|c|c|c|c|}
\hline Explosive & H-2223 & & C-4451 & & N-10829 & & O-6129 & & $\mathrm{Cl}-1165$ & \\
\hline HMX & $1.37 \mathrm{E}-008$ & 0.02 & $6.06 \mathrm{E}-008$ & 0.01 & $1.22 \mathrm{E}-010$ & 0.28 & $6.59 \mathrm{E}-008$ & 0.01 & $5.24 \mathrm{E}-009$ & 0.05 \\
\hline LX-17 & $1.27 \mathrm{E}-008$ & 0.03 & $9.07 \mathrm{E}-008$ & 0.01 & $5.29 \mathrm{E}-011$ & 0.41 & $5.32 \mathrm{E}-008$ & 0.01 & $5.85 \mathrm{E}-009$ & 0.05 \\
\hline TNT & $1.29 \mathrm{E}-008$ & 0.03 & $1.16 \mathrm{E}-007$ & 0.01 & $3.79 \mathrm{E}-011$ & 0.47 & $6.59 \mathrm{E}-008$ & 0.01 & $5.25 \mathrm{E}-009$ & 0.05 \\
\hline COMP. B & $1.36 \mathrm{E}-008$ & 0.02 & $8.15 \mathrm{E}-008$ & 0.01 & $1.04 \mathrm{E}-010$ & 0.31 & $6.60 \mathrm{E}-008$ & 0.01 & $5.26 \mathrm{E}-009$ & 0.05 \\
\hline TATB & $1.31 \mathrm{E}-008$ & 0.03 & $9.21 \mathrm{E}-008$ & 0.01 & $6.43 \mathrm{E}-011$ & 0.39 & $5.72 \mathrm{E}-008$ & 0.01 & 5.27E-009 & 0.05 \\
\hline PB-9501 & $1.41 \mathrm{E}-008$ & 0.02 & $6.44 \mathrm{E}-008$ & 0.01 & $1.06 \mathrm{E}-010$ & 0.3 & $6.61 \mathrm{E}-008$ & 0.01 & $5.25 \mathrm{E}-009$ & 0.05 \\
\hline PB-9502 & $1.28 \mathrm{E}-008$ & 0.03 & $9.13 \mathrm{E}-008$ & 0.01 & $5.82 \mathrm{E}-011$ & 0.38 & $5.48 \mathrm{E}-008$ & 0.01 & $5.74 \mathrm{E}-009$ & 0.05 \\
\hline NM & $1.83 \mathrm{E}-008$ & 0.02 & $6.88 \mathrm{E}-008$ & 0.01 & $4.95 \mathrm{E}-011$ & 0.39 & 7.76E-008 & 0.01 & $5.44 \mathrm{E}-009$ & 0.05 \\
\hline Anfo & $2.23 \mathrm{E}-008$ & 0.02 & $2.46 \mathrm{E}-008$ & 0.02 & $1.38 \mathrm{E}-010$ & 0.26 & $8.49 \mathrm{E}-008$ & 0.01 & 5.30E-009 & 0.05 \\
\hline Black Powder & $1.04 \mathrm{E}-008$ & 0.03 & $4.35 \mathrm{E}-008$ & 0.01 & $1.27 \mathrm{E}-011$ & 0.94 & $5.50 \mathrm{E}-008$ & 0.01 & $5.35 \mathrm{E}-009$ & 0.05 \\
\hline
\end{tabular}


15-KG pancake

\begin{tabular}{lrrrrrrrrrrrr}
\hline \multicolumn{1}{c}{ Explosive } & H-2223 & & C-4451 & & N-10829 & & O-6129 & & Cl-1165 \\
\hline HMX & $5.52 \mathrm{E}-008$ & 0.01 & $4.03 \mathrm{E}-007$ & 0 & $1.46 \mathrm{E}-009$ & 0.08 & $5.71 \mathrm{E}-007$ & 0 & $5.72 \mathrm{E}-009$ & 0.05 \\
LX-17 & $4.12 \mathrm{E}-008$ & 0.01 & $6.82 \mathrm{E}-007$ & 0 & $9.98 \mathrm{E}-010$ & 0.1 & $4.61 \mathrm{E}-007$ & 0 & $1.29 \mathrm{E}-008$ & 0.03 \\
TNT & $4.18 \mathrm{E}-008$ & 0.01 & $8.45 \mathrm{E}-007$ & 0 & $6.45 \mathrm{E}-010$ & 0.12 & $5.24 \mathrm{E}-007$ & 0 & $5.68 \mathrm{E}-009$ & 0.05 \\
COMP. B & $5.09 \mathrm{E}-008$ & 0.01 & $5.66 \mathrm{E}-007$ & 0 & $9.87 \mathrm{E}-010$ & 0.1 & $5.34 \mathrm{E}-007$ & 0 & $5.61 \mathrm{E}-009$ & 0.05 \\
TATB & $4.76 \mathrm{E}-008$ & 0.01 & $6.96 \mathrm{E}-007$ & 0 & $1.26 \mathrm{E}-009$ & 0.09 & $4.99 \mathrm{E}-007$ & 0 & $5.73 \mathrm{E}-009$ & 0.05 \\
PB-9501 & $5.88 \mathrm{E}-008$ & 0.01 & $4.29 \mathrm{E}-007$ & 0.01 & $1.43 \mathrm{E}-009$ & 0.09 & $5.58 \mathrm{E}-007$ & 0 & $5.74 \mathrm{E}-009$ & 0.05 \\
PB-9502 & $4.21 \mathrm{E}-008$ & 0.01 & $6.81 \mathrm{E}-007$ & 0 & $1.00 \mathrm{E}-009$ & 0.1 & $4.71 \mathrm{E}-007$ & 0 & $1.15 \mathrm{E}-008$ & 0.03 \\
NM & $7.54 \mathrm{E}-008$ & 0.01 & $3.54 \mathrm{E}-007$ & 0.01 & $6.12 \mathrm{E}-010$ & 0.12 & $5.00 \mathrm{E}-007$ & 0 & $5.45 \mathrm{E}-009$ & 0.05 \\
Anfo & $1.54 \mathrm{E}-007$ & 0.01 & $7.53 \mathrm{E}-008$ & 0.01 & $2.14 \mathrm{E}-009$ & 0.07 & $7.06 \mathrm{E}-007$ & 0 & $6.03 \mathrm{E}-009$ & 0.05 \\
Black Powder & $1.09 \mathrm{E}-008$ & 0.03 & $2.23 \mathrm{E}-007$ & 0.01 & $2.10 \mathrm{E}-010$ & 0.22 & $4.38 \mathrm{E}-007$ & 0 & $6.23 \mathrm{E}-009$ & 0.05 \\
\hline
\end{tabular}

\begin{tabular}{|c|c|c|c|c|c|c|c|c|c|c|}
\hline Explosive & H-2223 & & C-4451 & & N-10829 & & O-6129 & & Cl-1165 & \\
\hline HMX & $2.19 \mathrm{E}-008$ & 0.02 & $1.16 \mathrm{E}-007$ & 0.01 & 4.43E-010 & 0.15 & $1.47 \mathrm{E}-007$ & 0.01 & $5.58 \mathrm{E}-009$ & 0.05 \\
\hline LX-17 & $1.80 \mathrm{E}-008$ & 0.02 & $1.87 \mathrm{E}-007$ & 0.01 & 3.09E-010 & 0.18 & $1.19 \mathrm{E}-007$ & 0.01 & 7.45E-009 & 0.04 \\
\hline TNT & $1.90 \mathrm{E}-008$ & 0.02 & $2.44 \mathrm{E}-007$ & 0.01 & $2.51 \mathrm{E}-010$ & 0.19 & $1.47 \mathrm{E}-007$ & 0.01 & $5.56 \mathrm{E}-009$ & 0.05 \\
\hline COMP. B & $2.16 \mathrm{E}-008$ & 0.02 & $1.65 \mathrm{E}-007$ & 0.01 & $3.31 \mathrm{E}-010$ & 0.17 & $1.45 \mathrm{E}-007$ & 0.01 & 5.61E-009 & 0.05 \\
\hline TATB & $1.99 \mathrm{E}-008$ & 0.02 & $1.88 \mathrm{E}-007$ & 0.01 & $3.15 \mathrm{E}-010$ & 0.17 & $1.27 \mathrm{E}-007$ & 0.01 & 5.64E-009 & 0.05 \\
\hline PB-9501 & $2.35 \mathrm{E}-008$ & 0.02 & $1.25 \mathrm{E}-007$ & 0.01 & $3.94 \mathrm{E}-010$ & 0.16 & $1.46 \mathrm{E}-007$ & 0.01 & $5.58 \mathrm{E}-009$ & 0.05 \\
\hline PB-9502 & $1.86 \mathrm{E}-008$ & 0.02 & $1.87 \mathrm{E}-007$ & 0.01 & $2.93 \mathrm{E}-010$ & 0.18 & $1.21 \mathrm{E}-007$ & 0.01 & 7.13E-009 & 0.04 \\
\hline NM & $3.97 \mathrm{E}-008$ & 0.02 & $1.31 \mathrm{E}-007$ & 0.01 & $2.95 \mathrm{E}-010$ & 0.18 & $1.67 \mathrm{E}-007$ & 0.01 & $5.53 \mathrm{E}-009$ & 0.05 \\
\hline Anfo & $5.44 \mathrm{E}-008$ & 0.01 & $3.32 \mathrm{E}-008$ & 0.02 & $7.31 \mathrm{E}-010$ & 0.12 & $1.83 \mathrm{E}-007$ & 0.01 & 5.53E-009 & 0.05 \\
\hline Black Powder & $1.05 \mathrm{E}-008$ & 0.03 & 7.54E-008 & 0.01 & $6.35 \mathrm{E}-011$ & 0.4 & $1.25 \mathrm{E}-007$ & 0.01 & $5.54 \mathrm{E}-009$ & 0.05 \\
\hline
\end{tabular}

\section{Simulated Explosives DT source}

14-KG

\begin{tabular}{lrrrrrrrrrrr}
\hline \multicolumn{1}{r}{ Explosive } & H-2223 & & C-4451 & & N-10829 & & O-6129 & Cl-1165 \\
\hline HMX & $1.34 \mathrm{E}-007$ & 0.01 & $3.07 \mathrm{E}-007$ & 0.01 & $2.23 \mathrm{E}-009$ & 0.07 & $2.70 \mathrm{E}-007$ & 0.01 & $3.87 \mathrm{E}-009$ & 0.06 \\
LX-17 & $1.14 \mathrm{E}-007$ & 0.01 & $4.12 \mathrm{E}-007$ & 0 & $1.72 \mathrm{E}-009$ & 0.07 & $2.31 \mathrm{E}-007$ & 0.01 & $1.44 \mathrm{E}-008$ & 0.03 \\
COMP. B & $1.67 \mathrm{E}-007$ & 0.01 & $3.66 \mathrm{E}-007$ & 0.01 & $2.45 \mathrm{E}-009$ & 0.06 & $2.95 \mathrm{E}-007$ & 0.01 & $3.95 \mathrm{E}-009$ & 0.06 \\
\hline
\end{tabular}


Appendix B

\section{Elemental Ratios}




\section{Appendix B \\ Elemental Ratios}

Table B1. Elemental Ratios for 10-kg Explosive Mass.

\begin{tabular}{lllll}
\hline \multicolumn{1}{c}{ Explosive } & H/N-DT & H/N-Cf & C/O-Cf & C/O-DT \\
\hline HMX & $26.0(2.3)$ & $29.4(1.6)$ & $1.65(.09)$ & $0.68(.01)$ \\
LX-17 & $22.2(2.3)$ & $29.0(1.9)$ & $3.70(0.2)$ & $1.45(.03)$ \\
TNT & $42.6(5.2)$ & $47.0(3.5)$ & $3.96(0.19)$ & $1.58(.03)$ \\
Comp. B & $28.4(2.7)$ & $36.3(2.1)$ & $2.59(0.13)$ & $1.04(.02)$ \\
TATB & $24.7(2.3)$ & $28.0(1.6)$ & $3.40(0.18)$ & $1.37(.03)$ \\
PBX-9501 & $29.0(2.6)$ & $34.2(1.9)$ & $1.85(0.1)$ & $0.75(.02)$ \\
PBX-9502 & $23.6(2.4)$ & $28.3(1.8)$ & $3.59(0.19)$ & $1.42(.03)$ \\
NM & $98.1(1017)$ & $87.8(3.5)$ & $1.71(0.06)$ & $0.68(.01)$ \\
ANFO & $62.4(4.4)$ & $62.7(1.9)$ & $0.24(0.01)$ & $0.08(.002)$ \\
Black Powder & $3.73(1.1)$ & $0.51(0.07)$ & $1.17(0.05)$ & $0.46(.01)$ \\
TATP & & & $4.91(0.18)$ & $2.11(.04)$ \\
\hline
\end{tabular}

Table B2. Elemental Ratios for 5-kg Explosive Mass.

\begin{tabular}{lllll}
\hline \multicolumn{1}{c}{ Explosive } & H/N-DT & H/N-Cf & C/O-Cf & C/O-DT \\
\hline HMX & $25.6(3.1)$ & $28.8(1.5)$ & $1.72(.08)$ & $0.68(.01)$ \\
LX-17 & $23.2(3.4)$ & $29.7(1.9)$ & $3.74(.18)$ & $1.42(.03)$ \\
TNT & $45.4(8.0)$ & $48.8(3.7)$ & $4.03(.17)$ & $1.55(.03)$ \\
Comp. B & $29.7(3.9)$ & $35.8(2.1)$ & $2.66(.12)$ & $1.02(.02)$ \\
TATB & $25.8(3.5)$ & $27.4(1.5)$ & $3.58(.17)$ & $1.35(.03)$ \\
PBX-9501 & $27.3(3.2)$ & $33.6(1.8)$ & $1.90(.09)$ & $0.74(.02)$ \\
PBX-9502 & $25.7(3.7)$ & $29.2(1.9)$ & $3.66(.17)$ & $1.40(.03)$ \\
NM & $108(16)$ & $89.0(4.9)$ & $1.80(.08)$ & $0.67(.01)$ \\
ANFO & $65.3(6.5)$ & $65.6(2.6)$ & $0.24(.02)$ & $0.08(.002)$ \\
Black Powder & $3.4(1.2)$ & $0.84(.16)$ & $1.19(.06)$ & $0.46(.01)$ \\
TATP & & & $5.06(.23)$ & $2.12(.04)$ \\
\hline
\end{tabular}


Table B3. Cf Geometry Effects.

\begin{tabular}{lcccccc}
\hline \multicolumn{1}{c}{ Explosive } & H/N-Cf & H/N pancake & H/N cigar & C/O-Cf & C/O pancake & C/O cigar \\
\hline HMX & $27.5(1.2)$ & $30.5(1.1)$ & $28.8(1.9)$ & $1.75(.09)$ & $1.73(.05)$ & $1.70(.09)$ \\
LX-17 & $27.8(1.6)$ & $32.9(1.5)$ & $28.7(2.4)$ & $3.73(.18)$ & $3.72(0.1)$ & $3.65(.2)$ \\
TNT & $43.8(2.6)$ & $55.6(3.3)$ & $47.7(4.7)$ & $4.10(.18)$ & $3.94(0.1)$ & $3.96(.19)$ \\
Comp. B & $33.8(1.6)$ & $39.9(1.7)$ & $37.1(2.8)$ & $2.69(.13)$ & $2.60(.07)$ & $2.55(.13)$ \\
TATB & $28.1(1.4)$ & $29.7(1.2)$ & $27.4(2.0)$ & $3.47(.17)$ & $3.45(.09)$ & $3.38(.18)$ \\
PBX-9501 & $33.2(1.5)$ & $35.0(1.1)$ & $33.6(2.3)$ & $1.93(.09)$ & $1.93(.05)$ & $1.90(.1)$ \\
PBX-9502 & $28.2(1.5)$ & $32.5(1.4)$ & $30.0(2.4)$ & $3.61(.18)$ & $3.58(0.1)$ & $3.57(.19)$ \\
NM & $87.1(2.9)$ & $98.4(5.2)$ & $89.5(6.3)$ & $1.71(.06)$ & $1.72(.05)$ & $1.80(.09)$ \\
ANFO & $62.3(1.6)$ & $68.1(2.0)$ & $64.0(3.2)$ & $.23(.01)$ & $0.22(.01)$ & $0.23(.02)$ \\
Black Powder & $0.51(0.1)$ & $0.65(0.08)$ & $0.98(1.14)$ & $1.24(.05)$ & $1.25(.04)$ & $1.14(.07)$ \\
TATP & -- & -- & $4.92(.25)$ & $4.95(.16)$ & $4.96(.14)$ & - \\
\hline
\end{tabular}

